\title{
Diyanet TV Çizgi Filmlerinin 4-6 Yaş Grubu Kur'an Kursu Öğretim Programında Yer Alan Değerler Açısından İncelenmesi
}

\section{Investigation of Diyanet TV Cartoons in Terms of the Values Included in the 4-6 Age Group Koran Courses Curriculum}

\author{
Semra ÇINEMRE, Sorumlu Yazar, Dr. Öğr. Üyesi. \\ Trabzon Üniversitesi, İlahiyat Fakültesi, Trabzon / Türkiye. \\ semra.cinemre@trabzon.edu.tr \\ https://orcid.org/0000-0002-2924-1129
}

ISSN: 1303-880X

e-ISSN: 2667-7504

http://ded.dem.org.tr

Makale Türü / Article Type:

Araştırma Makalesi / Research Article

Geliş Tarihi / Received Date: 10.01.2021

Kabul Tarihi / Accepted Date: 31.03 .2021

Yayın Tarihi / Published Date: 25.06.2021

Tr/En: $\mathrm{Tr}$

Intihal / Plagiarism: Bu makale, en az iki hakem tarafindan incelendi ve intihal içermediği teyit edildi. / This article has been reviewed by at least two referees and scanned via a plagiarism software.
Atıf/Citation:Çinemre, S. (2021). Diyanet TV çizgi filmlerinin 4-6 yaş grubu Kur'an Kursu öğretim programında yer alan değerler açısından incelenmesi. Değerler Ĕgitimi Dergisi, 19 (41), s.207-243.

https://doi.org/10.34234/ded.857721 
Öz: Diyanet İşleri Başkanlığı, günümüz bilgi ve iletişim teknolojisinin imkânlarını kullanarak toplumun tüm kesimleri için yayınlar hazırlamayı kendisine ilke ve hedef olarak belirlemiştir. Bu çalışmada Başkanlığın çocuk hedef kitleye yönelik hizmetlerinden biri olan Diyanet TV çizgi filmlerinin değerler açısından incelenmesi amaçlanmaktadır. Bu amaç doğrultusunda 4-6 Yaş Grubu Kur'an Kursları Öğretim Programının Dini Bilgiler-1 öğrenme alanında yer alan ünite isimleri temel alınarak 11 analiz kategorisi belirlenmiştir. Çalışmanın örneklemi olarak Dedemin Öyküleri ve Yusuf'un Dünyası çizgi filmleri seçilmiştir. Nitel araştırma yönteminin benimsendiği çalışmada doküman incelemesi yolu tercih edilmiş ve veriler içerik analizi ile çözümlenmiştir. Bulguların yorumlanmasında çeşitli çizgi filmlerin değerler açısından incelendiği literatür sonuçlarından, örgün eğitim için belirlenmiş olan kök değerlerden, okul öncesi eğitimi ve Hayat Bilgisi dersi öğretim programlarından yararlanılmıştır. Çalışmanın sonunda her iki çizgi filmde de en sık yer verilen değerin yardımlaşma; hiç yer verilmeyen değerin ise iyilik olduğu görülmüştür. Bunun yanı sıra Dedemin Öykülerinde sayg1; Yusuf'un Dünyasında adalet, merhamet/şefkat ve sorumluluk değerlerine hiç yer verilmediği tespit edilmiştir. Çalışmanın nihayetinde Diyanet TV çizgi filmlerinin değerleri görece destekleyen bir içerik sunmakla birlikte analiz kategorisi olarak temel alınan öğretim programının değerleri açısından yetersizlik arz ettiği sonucuna ulaşılmış ve geliştirilmesine dönük birtakım önerilerde bulunulmuştur.

Anahtar Kelimeler: Değerler eğitimi, Yaygın din eğitimi, 4-6 Yaş Kur'an Kursu Öğretim Programı, Diyanet TV, Çizgi film.

$\&$

Abstract: The Presidency of Religious Affairs has established a set of principles and goals to communicate with all strata of society, using possibilities of today's communication technology. This study aimes to examine the cartoons on Diyanet TV having children as its target audience in terms of values acquisition. Accordingly, 11 analysis categories were determined based on the 4-6 Age Group Koran Courses Curriculum. The sample of the study are Dedemin Öyküleri ve Yusuf'un Dünyası cartoons. Qualitative research method was adopted, document analysis method was preferred and the data were analyzed by content analysis. At the end of the study, it has been seen that in both cartoons the most common value is solidarity whereas the value that is not included at all is goodness. In addition, it has been found that in Dedemin Öyküleri respect and in Yusuf'un Dünyası justice, compassion/mercy and responsibility are the values that not included. Finally, the last section of the study concludes that Diyanet TV cartoons provide a content that supports 
values acquisition, but are not substantially parallel with the values in the relevant curriculum, and some suggestions have made for their improvement.

Keywords: Values education, Non-formal religious education, 4-6 Age Koran Courses Curriculum, Diyanet TV, Cartoon.

(The Extended Abstract is at the end of the article)

\section{Giriş}

Bilgi ve iletişim teknolojisi araçlarının her geçen gün yaygınlaşması ve çeşitlenmesi ile birlikte geleneksel kurumlar olan aile ve okulun, bilgi sunma ve toplumsallaştırma gibi rolleri bu araçlar tarafından etkin bir şekilde üstlenilmiştir. Bu bağlamda kitle iletişim araçlarının birey ve topluma dönük tutum belirleme, sosyalizasyon, kültür aktarma yönleri başta olmak üzere çeşitli açılardan bir yaygın eğitim aracı olma işlevinden söz edilmektedir (Arslan, 2016, ss. 8-9). Hemen her yaştan kimse için çeşitli bilgi içeriklerinde söz konusu olan bu durum, çocuk hedef kitle için de geçerlidir. Nitekim çocukların hayatında aile ve okul gibi kurumların yanı sıra kitle iletişim araçlarının birçok bakımdan rol oynadığı bilinen bir gerçektir. Bu noktada konuya okul öncesi dönem çocukları açısından bakıldığında, çeşitli çalışmalarda, en yaygın araç olarak televizyonun ve program kategorisi olarak da çizgi filmlerin erken çocukluk döneminden itibaren çocukların ahlak gelişimine, sözlü ve sözsüz iletişimlerine, bilişsel ve duyuşsal dünyalarının şekillenmesine çeşitli açılardan olumlu veya olumsuz etkisinin olabileceği; çocuğun modelleme sürecinde ve davranış değişikliklerinde önemli bir paya sahip olduğu belirtilmektedir (Büyükbaykal, 2007; Oruç vd., 2011; Cebeci ve Demir, 2018; Güloğlu, 2019; Yazıc1 vd., 2019).

Kitle iletişim araçlarının çeşitli temalarda bir yaygın eğitim aracı olma yönü din ve değerler eğitimi açısından da söz konusudur. Bu bağlamda modern toplumlarda, geleneksel toplumlardan farklı olarak dini kimlik oluşturmanın en etkin yolunun kitle iletişim araçlarından geçtiği, bu noktada da bu araçların, günümüzde aile ve cami gibi geleneksel dini sosyalleşme araçlarına ek olarak "modern dini sosyalizasyon" araçları olarak işlev gördüğüne dikkat çekilmektedir (Arslan, 2016, ss. 10-11). Bu hususta kitle iletişim araçlarının, dini açıdan bilgilendirme, dini kimlik oluşturma ve dini davranış veya tutum kazandırmada etkin bir rol oynayabildiği, bu anlamda da medyanın bir yaygın din eğitimi aracı olarak değerlendirilebileceği belirtilmektedir (Furat, 2009, s. 56). Diyanet İşleri Başkanlığı da bu gelişmeleri dikkate alarak kitle iletişim araçlarının imkanlarını ve yaygın etkisini kullanmada önemli adımlar atmıştır. Bu bağlamda Başkanlık, "günümüz bilgi, bilişim ve iletişim teknolojisinin imkânlarını olabildiğince 
iyi kullanarak topluma dini bilgi sunmak, çocuk ve gençleri kötü alışkanlık ve zararlı akımlardan korumaya yönelik yayınlara öncelik vermek, toplumu din konusunda sahih kaynaklara dayalı, doğru bilgiyle aydınlatmak" gibi hedefler belirlemiş olup bu kapsamda Dini Yayınlar Genel Müdürlüğü bünyesinde çeşitli çalışmalar yürütmektedir (Dini Yayınlar Genel Müdürlüğü). Başkanlığın bu hedefleri doğrultusunda hizmetlerini yürüttüğü çeşitli radyo ve televizyon kanallarından biri, TRT işbirliği ile 2012 yılında "TRT Diyanet" adıyla kurulan, 1 Ocak 2019 tarihi itibariyle hizmetlerini "Diyanet TV" adı ile yürüten televizyon kanalıdır. Diyanet TV'de çeşitli hedef kitlelere hitap eden yayınlardan biri de çocuklara yönelik programlar ve bu kapsamda çizgi filmlerdir.

Başkanlığın, çocuk hedef kitleye yönelik bir başka hizmeti de Din Hizmetleri Genel Müdürlüğü çalışmaları bünyesinde 2013 yılı itibariyle pilot uygulama ile başlattığı 4-6 yaş grubu Kur'an kurslarıdır. Bu kursların öğretim programına bakıldığında, Başkanlığın bu hizmeti ile çocukların sevgi, saygı, yardımlaşma, iyilik, adalet, sorumluluk, doğruluk ve sabır gibi İslam dininin temel değerlerini fark etmeleri, bunun yanı sıra Kur'an-1 Kerim'i ses ve şekil olarak kendi seviyelerinde tanımalarının hedeflendiği görülmektedir (Kur'an Kursları Öğretim Programı-4-6 Yaş Grubu, 2018). Programın içeriği de bu hedef doğrultusunda yapılandırılmış olup Dini Bilgiler 1-2 ile Kur'an-1 Kerim 1-2 olmak üzere temelde iki öğrenme alanından oluşmaktadır. Her öğrenme alanında dokuz ünite yer almaktadır. Dini bilgiler öğrenme alanlarının ilki çeşitli değerlerden oluşmakta; ikincisi ise din sevgisi, insan ve kainat sevgisi ve milli değerleri konu edinmektedir. Kur'an'1 Kerim öğrenme alanı da Kur'an'1 tanıma, harfleri ve harekeleri tanıma ve ezber üzerinedir.

Başkanlığın, hizmetlerini toplumun tüm kesimlerine ulaştırma ilke ve hedefleri doğrultusunda çocuk hedef kitleye yönelik sunduğu bu çalışmalarının farklı açılardan incelenmesi gerekmektedir. Zira ancak bu suretle, hizmetlerinin çeşitli perspektiflerden ele alınarak eksikleri ve geliştirilmesi gereken yönleri ortaya konularak niteliğinin artırılmasına katkı sunulabilir. Literatürde her ne kadar Başkanlığın 4-6 yaş grubu Kur'an kurslarını inceleyen çeşitli çalışmalar varsa da yine çocuk hedef kitleye yönelik hizmetlerinden biri olan çizgi filmleri inceleyen bir çalışma bulunmamaktadır. Bununla birlikte çizgi filmleri değerler açısından çeşitli kriterlere göre ele alan makaleler bulunmaktadır. Bunlardan bazısında çizgi filmler çeşitli derslerin öğretim programlarında yer alan değerler açısından analiz edilmiştir: Karakuş (2015) Niloya isimli çizgi filmi Sosyal Bilgiler dersi (6. ve 7. sınıf); Selanik Ay ve Korkmaz (2017) Küçük Hezarfen çizgi filmini Sosyal Bilgiler dersi; Sadioğlu vd., (2018) Rafadan Tayfa çizgi filmini Hayat Bilgisi dersi ve Şahin (2019) Rafadan Tayfa ve Arı Maya çizgi film- 
lerini Türkçe dersi öğretim programında yer alan değerler açısından; Şentürk ve Keskin (2019) ise Rafadan Tayfa çizgi filmini kök değerler çerçevesinde milli ve evrensel değerler açısından incelemiştir. Çizgi filmleri öğretim programları dışında, çeşitli kriterlere göre ele alan çalışmalar ise şunlardır: Yorulmaz (2013a ve 2013b) Caillou ve Pepee çizgi filmlerini farklı kültürlere ait ve İslam dinine ait unsurların, şiddet ve cinsellik unsurlarının, değerleri geliştirici iletilerin, batıl inanç içeren iletilerin yer alma durumu, çizgi film kahramanlarının karakter özellikleri, alt metin ve bilinçaltı mesajlar, aile yapısının özellikleri gibi çeşitli kriterler açısından analiz etmiş̧tir. Yaman vd., (2015) tarafından yapılan çalışmada Dede Korkut çizgi filmi karma yöntemle çeşitli kriterler açısından incelenmiş; Cebeci ve Demir tarafından yapılan çalışmada da (2018) yerli yapım Rafadan Tayfa ve yabancı yapım Doraemon çizgi filmleri dinî-kültürel değerler açısından analiz edilmiştir.

Bu çalışmada Diyanet İşleri Başkanlığı'nın Diyanet TV kanalında yayınlanan çizgi filmler değerler açısından incelenecektir. Çalışmanın analizine konu olan nesne Diyanet İşleri Başkanlığı'nın bir hizmeti olduğundan analiz kategorilerini belirlemede de yine Başkanlığın bir başka yaygın din eğitimi hizmeti olan 4-6 yaş grubu Kur'an kurslarının öğretim programında yer alan değerler temel alınacaktır. Bununla birlikte yorum ve analizleri derinleştirmek amacıyla değerlerin çizgi filmlerde ele alınış kapsam ve düzeyi, ilgili öğretim programında yer alan kazanımlarla ilişkilendirilecek ve örgün eğitim için belirlenmiş olan kök değerler, okul öncesi eğitimi ve Hayat Bilgisi dersi öğretim programları ile de karşılaştırmalar yapılacaktır. Bu doğrultuda çalışmada "Diyanet TV çizgi filmleri değerleri destekleyen bir içerik sunmakta mıdır?" temel problemi çerçevesinde aşağıdaki sorulara yanıt aranacaktır:

- Diyanet TV çizgi filmlerinde en sık hangi değerlere yer verilmektedir?

- Diyanet TV çizgi filmlerinde en az hangi değerlere yer verilmektedir?

- Diyanet TV çizgi filmlerinde değerler hangi bağlam ve kapsamda ele alınmaktadır?

\section{Yöntem}

Nitel araştırma yönteminin benimsendiği bu çalışmada doküman analizi yolu tercih edilmiştir. Doküman analizinde çeşitli yazılı kaynakların yanı sıra film, video ve fotoğraf gibi görsel ve dijital materyaller de incelenebilmektedir (Y11dırım ve Şimşek, 2008, ss. 39, 189). Bu doğrultuda, bu çalışmada çizgi filmler bir doküman olarak ele alınıp içerik analizi yöntemiyle analiz edilecektir. 


\section{Örneklem}

Diyanet TV'de yayınlanmış/yayınlanmakta olan Bilim Hazinesi, Dedemin Öyküleri, Gezgin ile Merakl, Harfler Köyü, Yusuf'un Dünyası ve Şeker Hoca isimli altı çizgi film bulunmaktadır. Araştırmanın çizgi film örneklemi amaçlı örnekleme tekniklerinden tipik durum örneklemesi ile belirlenmiştir. Tipik durum örneklemesinde, bir uygulama konusunda en tipik olan ortalama durumlar seçilerek belirli bir alan hakkında fikir sahibi olmak veya bu alan, konu, uygulama veya yenilik konusunda yeterli bilgi sahibi olmayanları bilgilendirmek amaçlanmaktadır. (Patton, 1987'den aktaran Yıldırım ve Şimşek, 2008, s. 110). Tipik durum örneklemesinde sıra dışı olmayan, ortalama durumlar kastedildiği için Arapça harflerin tanıtıldığı, fikralara yer verilen ve yayın sayısı 10 bölüm altında olan üç çizgi film ortalama durumlar olarak kabul edilmeyerek elenmiştir. Geriye kalan üç çizgi filmin tümünün örnekleme dahil edilmesi durumunda çok fazla veri elde edileceği düşüncesiyle bunlar içerisinden Dedemin Öyküleri ve Yusuf'un Dünyası çizgi filmleri seçilmiştir.

Bölüm örneklemesi olarak da her iki çizgi filmden ilk 10 bölüm seçilmiştir. Bazı çizgi filmlerin bölüm isimleri bizzat analiz kategorilerinde yer alan değerler olduğu için örneklem seçiminde bu durumdan etkilenilmemesi ve böylece bir çizgi film açısından seçilen bölümlere bağlı olarak değerlere ilişkin daha yoğun veri elde edilmemesini sağlamak düşüncesiyle her iki çizgi filmden de standart olarak ayn bölüm aralığı seçilmiştir. Dedemin Öyküleri sadece 13 bölümden oluştuğu için de bu aralık, iki çizgi film için de ilk 10 bölüm olarak belirlenmiştir.

Dedemin Öyküleri 13; Yusuf'un Dünyası ise 26 bölümden oluşmaktadır. Çizgi filmlerin yayın süreleri 6-12 dakika arasında değişmektedir. Örneklemi oluşturan çizgi filmlerin bölüm isimleri ve yayın süreleri Tablo 1'de gösterilmiştir.

\begin{tabular}{lllll}
\hline \multicolumn{2}{l}{ Tablo 1: Örnekleme Dahil Edilen Çizgi Film Bölüm Listesi } & \\
\hline Bölüm No & $\begin{array}{l}\text { Dedemin Ö̈küleri } \\
\text { Bölüm Adı }\end{array}$ & Bölüm süresi & $\begin{array}{l}\text { Yusuf'un Dünyası } \\
\text { Bölüm Adı }\end{array}$ & Bölüm süresi \\
\hline 1 & Merhamet & $7.09 \mathrm{dk}$. & Tanışma & $8.21 \mathrm{dk}$. \\
\hline 2 & Sabretmek & $8.23 \mathrm{dk}$. & Yardımlaşma & $9.16 \mathrm{dk}$. \\
\hline 3 & Paylaşmak & $8.14 \mathrm{dk}$. & Paylaşma & $9.13 \mathrm{dk}$. \\
\hline 4 & Dürüstlük & $6.10 \mathrm{dk}$. & Özür Dilerim & $8.18 \mathrm{dk}$. \\
\hline 5 & Yardımlaşmak & $8.23 \mathrm{dk}$. & Beni Bırakma & $8.08 \mathrm{dk}$. \\
\hline 6 & Sorumluluk & $8.04 \mathrm{dk}$. & Kuzenler Geldi & $9.37 \mathrm{dk}$. \\
\hline 7 & Dua etmek & $8.17 \mathrm{dk}$. & Abdest & $8.09 \mathrm{dk}$. \\
\hline 9 & Israf etmemek & $6.27 \mathrm{dk}$. & Namazla tanışma & $7.03 \mathrm{dk}$. \\
\hline 10 & Adaletli olmak & $7.20 \mathrm{dk}$. & Su damlası & $9.49 \mathrm{dk}$. \\
\hline
\end{tabular}




\section{Araştırma Süreci}

Araştırmanın verileri, çizgi filmlere ait bölümlerin Diyanet TV kanalının internet sayfasından erişilmesiyle toplanmıştır (https://www.diyanet.tv/cocuk). Elde edilen veriler içerik analizi ile çözümlenmiştir. İçerik analizinde kitap, gazete ve dergi, reklam, resmi belge, film, video kaydı ve fotoğraf incelenebilmektedir (Neuman, 2006, s. 466). Bu çalışma için seçilen çizgi filmlerin analizinde açık kodlama (Neuman, 2006, ss. 468-471) yolu tercih edilmiş; bu bağlamda yalnızca sözel içerikler dikkate alınarak yüzeydeki içerik kodlanmış; görsel içeriklerde, seçilen müziklerde, kahramanların beden dili veya kıyafetlerinde yer alabilecek alt mesajlar, yan anlamlar gibi örtük kodlama (Neuman, 2006, ss. 468-471) ile aranan içerikler değerlendirilmemiştir. Bilimsel araştırmaların güvenirliği açısından bakıldığında; bu araştırmada da izlenen açık kodlama yolunun örtük kodlamaya nazaran oldukça güvenilir olduğu, zira yan veya örtük anlamlarla ilgilenmeyip kod olarak belirlenen kavramların, analiz edilen içerikte olup olmadığının tespit edildiği, bunun da kodlayıcının ön bilgisi, dil ve anlam bilgisi gibi yeterlikleri ile ilgisi olmadığı bilinmektedir (Neuman, 2006, ss. 470-471).

İçerik analizinde kategori sistemi ve buna bağlı kodlama oldukça önemli bir aşamadır. Bu durum, çalışmanın geçerlik ve güvenirliği açısından da kritiktir. Zira belirsiz kategoriler güvenirliği azaltacağından ötürü kategoriler açık seçik olmalı (Bal, 2013, s. 187), bu noktada da kategorilerin nasıl oluşturulduğu, bu kapsamda hangi kodların belirlendiği, analize nelerin dahil edildiği, nelerin hariç tutulduğu gibi detaylara yer verilmelidir. Bu boyutları açıklamak gerekirse; bu çalışmanın analiz kategorilerinin belirlenmesinde 4-6 Yaş Grubu Kur'an Kursları Öğretim Programı temel alınmıştır. Bu çalışmanın giriş bölümünde bahsedildiği üzere, öğretim programının Kur'an’1 Kerim 1-2 öğrenme alanı Kur'an'1, harfleri ve harekeleri tanıma odaklı olması nedeniyle analiz kategorisi dışında tutulmuştur. Dini Bilgiler 1-2 öğrenme alanlarından Dini Bilgiler-1 ünite isimleri bire bir değer kavramlarından oluştuğu için araştırmanın odağ olan çizgi filmlerin değerler açısından incelenmesinde kategori olarak alınmaya uygun görülmüştür. Bu ünite listesi öğretim programında yer verilen sıraya göre şu şekildedir: "Dua, şükür ve özür dileme", "Sevgi ve merhamet", "Sayg1", "Sorumluluk", "Yardımlaşma", "Sabır”, "İyilik”, "Doğruluk ve dürüstlük”, "Adalet". Dini Bilgiler-1 öğrenme alanında yer alan bu ünite isimleri değerler eğitimi analizi açısından birtakım değişiklikle birlikte analiz kategorisi olarak alınmıştır. Bu bağlamda "dua", din eğitimine ilişkin bir kavram olarak değer- 
lendirilerek değer kategorisi dışında tutulmuştur. Bunun yanı sıra, bir arada yer verilen sevgi ve merhamet ile şükür ve özür dileme kavramları da bağlamları farklı olduğu için ve kategorilerin iç homojenlik/dış heterojenliğinin sağlanması ilkeleri gereğince ayrı değerler olarak ele alınmıştır. Buna ek olarak merhamet ile şefkat yakın anlamlarda olduğu için aynı analiz kategorisinde birleştirilmiş; şükür kavramına da teşekkür değeri ilave edilerek aynı analiz kategorisinde yer verilmiştir. Böylece değerlere ilişkin şu 11 analiz kategorisi belirlenmiştir: Adalet, Doğruluk/Dürüstlük, İyilik, Merhamet/Şefkat, Özür dileme, Sabır, Sayg1, Sevgi, Sorumluluk, Şükür/Teşekkür, Yardımlaşma. Analiz kategorilerinin belirlenmesine yönelik bu çalışmada yine araştırmanın geçerlik güvenirliğini artırmaya dönük olarak kategori isimlerinin bütüncül ve kapsamlı olmasına dikkat edilmiş, bunun yanında iç homojenlik ve dış heterojenlik ilkelerine uygunluk sağlanmıştır. İç homojenlikte verilerin ait oldukları kategori ile ne kadar bütünlük sağladıklarına, dış heterojenlikte ise kategoriler arasındaki farkların net ve belirgin olmasına dikkat edilmiştir. Bu kapsamda, değerler birbirinden farklı bağlamlarda olup kodları da olduğu gibi ilgili değerin ya kendisi ya da türevleri olduğu için iç homojenlik ve diş heterojenlik sağlanmıştır.

Analiz kategorilerine uygun kodlar belirlemede daha önceden belirlenmiş kavramlara göre yapılan kodlama (Yıldırım ve Şimşek, 2008, s. 229) yolu tercih edilmiştir. Bu doğrultuda yapılan analizde; kategori olarak belirlenen sözcüklerin veya aynı kökten türevi olan sözcüklerin kullanılması kod olarak kabul edilmiştir. Örneğin sözel içeriklerde "şükür", "sabır”, "sevgi”, "adalet” gibi ifadeler kod olarak kabul edileceği gibi "şükretmek", "sabırlı olmak", "sevmek", "adil olmak" gibi sözcükler de aynı kapsam ve muhtevada olduğu için kod olarak kabul edilmiştir.

Çalışmada kodlama süreci; açık ve eksenli kodlama olmak üzere iki aşamalı olarak gerçekleştirilmiştir. Açık kodlama, nitel verileri ilk kodlama olup verilerin üzerinden ilk geçişte gerçekleştirilir (Neuman, 2006, s. 664). Açık kodlamada her çizgi film bölümü arka arkaya iki kez izlenerek kodlama yapılmıştır. Çizgi filmlerin ilk izlenmesinde yapılan kodlama daha önceden belirlenmiş kavramlara göre yapılan kodlama listesine göre yapılmıştır. İkinci izlemede, ilk kodlamada alınan notlar gözden geçirilerek geliştirilmiştir. Üçüncü izleme ise eksenli kodlamaya göre yapılmıştır. Eksenli kodlama verilerin üzerinden "ikinci geçiş” olarak tanımlanmaktadır. Bu ikinci geçişte verilerden çok başlangıçta kodlanan temalara odaklanılmış, fikirler ve temalar gözden geçirilerek düzenlenmiştir (Neuman, 2006, s. 667). 
Araştırmanın geçerliğini artırmak ve aktarılabilirlik kriterlerine uygunluğunu sağlamak açısından doğrudan alıntılara yer verilmesi önemli olduğundan (Y11dırım ve Şimşek, 2008, ss. 258, 270); bulguların sunumunda çizgi filmlerden kesitler veya bağlamlara sıklıkla yer verilmiştir.

\section{Bulgular}

$\mathrm{Bu}$ bölümde bulgular, analiz kategorisi olarak belirlenmiş olan değer başlıklarına göre sunulacaktır. Bulguları yorumlarken çizgi filmlerden yer yer kesitler verileceği için şu aşamada her ikisinden de kısaca bahsetmek yararlı olacaktır. Dedemin Öyküleri çizgi filminde Sare ve Cihan isimli iki kardeş, dedesi ve ninesi ile birlikte bir köyde yaşamaktadır. Bu köyde Ali isimli bir arkadaşları ile Kıvırcık adında bir kuzuları vardır. Her bölümde dede, bölümün teması kapsamında çocuklara peygamberler başta olmak üzere çeşitli konularda öyküler anlatmaktadır. Bu çizgi filmde bölüm konuları birbirinden bağımsızdır. Yusuf'un Dünyası çizgi filminin ise başrol oyuncusu Yusuf 4. sınıf, kardeşi Elif 3. sınıf, en küçük kardeşi Osman da anaokulu öğrencisidir. Aile; anne, baba, dede ve çocuklardan oluşmaktadır. Evde kendileri ile birlikte yaşayan Minyon isimli bir kedileri ile bahçedeki kulübede yaşayan Karabaş isimli köpekleri vardır. Her bölümde Yusuf ve kardeşlerinin başına gelen olaylar ele alınmaktadır. Bölümlerde ayrı konular işlenmekle birlikte bölümlerin kendi arasında bir ardışıklığı bulunmaktadır.

\section{Adalet Değerine İlişkin Bulgular}

Çizgi filmlerde adalet değerine yer verilme durumu Tablo 2'de gösterilmiştir.

Tablo 2: Çizgi Filmlerde Adalet Değerine Yer Verilme Durumu

\begin{tabular}{lll}
\hline Adalet Değeri & Değere Çizgi Filmde Yer Verilme Sıklığı & Değere Yer Verilen Bölüm No \\
\hline Dedemin Öyküleri & 2 & 9 \\
\hline Yusuf'un Dünyası & - & - \\
\hline
\end{tabular}

Adalet değerinin Dedemin Öyküleri çizgi filminde iki kez geçtiği; Yusuf'un Dünyasında ise bu değere hiç yer verilmediği görülmektedir.

Dedemin Öykülerinde adalet değeri, Adaletli Olmak bölümünde çocukların kendi aralarındaki bir oyun esnasında ele alınmaktadır. Burada tornet sürme yarışı yapan çocuklardan tornetinin tekerlekleri büyük olan çocuk yarışı kazanır. Tornetinin tekerleri küçük olan Cihan yarışı kaybedince birinciliğin aslında 
kendi hakkı olduğunu, çünkü arkadaşının tornetinin tekerlerinin daha büyük olduğunu söyler. Sonra dede "Her durumda adil davranmak çok önemlidir, bu bizi üzecek olsa bile.” der ve Hz. Muhammed zamanında yaşayan ve mallarına el konulan tüccarın "İçinizde hakkı, adaleti bilen kimse yok mu?" diye seslendiği, bunun üzerine Hz. Muhammed'in de içinde olduğu bir grubun Mekke'de insanların haklarının korunması, haksızlık yapılmaması kararı aldıklarını anlatır. Bu kez Cihan, arkadaşına haksızlık ettiğini, birinciliğin zaten arkadaşının hakk1 olduğunu söyler ve özür diler (9. bölüm). Burada adalet değerinin; hak, haksızlık ve adil davranmak kavramları çerçevesinde işlendiği görülmektedir. Adalet değerine ilişkin sunulan bu içerik, öğretim programında bu değer kapsamında yer alan sekiz kazanımdan üçünü destekler niteliktedir. Burada çocuk, önce yapılan durumun kendisi açısından adaletsizlik olduğunu düşünmekte, sonucu kabul etmeyerek hakkını savunmakta fakat daha sonra dedesinin yaptı̆̆ açılama ile fikrini değiştirerek yapılanın adaletsizlik olmadığını ayırt etmektedir. Bu bağlamda bu içerik, "Kendisinin ve başkalarının haklarını korur." ve "Adil olan ve olmayan davranışları ayırt eder." kazanımlarını desteklemektedir. Dedenin, Hz. Peygamber döneminden aktardığı örnek olay ise "Peygamberimizin herkese adil davrandığını bilir." kazanımı ile örtüşmektedir. Bu bağlamda adalet değerinin, çocuklara bilgi temeli sunan ve ayrıca ayırt etme bilişsel becerisi sağlamaya dönük bir içerikle işlendiği görülmektedir.

Literatürde çizgi filmleri değerler açısından inceleyen çalışmalara bakıldığında adalet değerinin çizgi filmlerde en az geçen değerlerden biri olduğu görülmektedir. Örneğin; Niloya çizgi filminin 18 bölümünde 22 değer içerisinde adil olmak değerinin üç kez geçtiği (Karakuş, 2015); Küçük Hezarfen çizgi filminde 21 değerden biri olarak iki kez geçen adil olma değerinin en az yer alan değerlerden biri olduğu (Selanik Ay ve Korkmaz, 2017); Rafadan Tayfa çizgi filminin 40 bölümünde 20 değer içerisinde adalete $\% 5$ oranında yer verildiği (Sadioğlu vd., 2018); yine Rafadan Tayfa çizgi filminin üç bölümünde 21 değer arasında adalet değerine rastlanmadığı (Şahin, 2019); Rafadan Tayfa çizgi filmini inceleyen farklı bir çalışmada da belirlenen 10 evrensel değerden biri olarak adaletin en az işlenen değerlerden biri olduğu ortaya konulmuştur (Şentürk ve Keskin, 2019). Bu sonuç, gerek genel olarak birçok çizgi filmde gerekse bu çalışmada incelenen Diyanet TV çizgi filmlerinde adalet değerinin sınırlı kapsamda ele alındığını göstermektedir.

Örgün eğitimin öğretim programlarına bakıldığında adalet değerinin, tüm dersler için belirlenen 10 kök değerden biri olup okul öncesi eğitimi ve Hayat 
Bilgisi dersi öğretim programlarında da bu değeri destekleyen kazanım veya açıklamalar bulunduğu görülmektedir (Okul Öncesi Eğitim Programı, 2013, s. 28; Hayat Bilgisi Dersi Öğretim Programı, 2018, s. 19). Ayrıca değerlerin önemi ve önceliğinin incelendiği çeşitli çalışmalarda da adalet değerinin öğretmenler tarafından birinci veya ikinci önem sırasında gösterildiği ortaya konulmuştur (Balc1 ve Yanpar Yelken, 2013; Arpacı, 2014; Ünlü ve Kaşkaya, 2018; Kılcan, 2020). Bu bağlam da dikkate alındığında çizgi filmlerde en temel ve öncelikli değerlerden biri olan adalete yetersiz bir düzey ve kapsamda yer verilmiş olduğu görülmektedir.

\section{Doğruluk/Dürüstlük Değerine İlişkin Bulgular}

Çizgi filmlerde doğruluk/dürüstlük değerine yer verilme durumu Tablo 3’te gösterilmiştir.

Tablo 3: Çizgi Filmlerde Doğruluk/Dürüstlük Değerine Yer Verilme Durumu

\begin{tabular}{lll}
\hline $\begin{array}{l}\text { Doğruluk/Dürüstlük } \\
\text { Değeri }\end{array}$ & $\begin{array}{l}\text { Değere Çizgi Filmde Yer Verilme } \\
\text { Sıklığı }\end{array}$ & $\begin{array}{l}\text { Değere Yer Verilen Bölüm } \\
\text { No }\end{array}$ \\
\hline Dedemin Öyküleri & 3 & 4 \\
\hline Yusuf'un Dünyası & 1 & 4 \\
\hline
\end{tabular}

Doğruluk/dürüstlük değerinin Dedemin Öyküleri çizgi filminde üç, Yusuf'un Dünyasında ise bir kez geçtiği görülmektedir.

Dedemin Öykülerinde müstakil olarak Dürüstlük bölümünde bu değer ele alınmaktadır. Dedesi ortada bir hata gördüğünde bunu Sare'nin kendisinin mi yaptığını sorduğunda Sare hemen doğruyu söyler. Dede, bunun üzerine Hz. Ömer döneminde süte su katan annesine müdahale eden kızın hikayesini anlatır. Sare, yaptığı hata için dedesinin kendisine kızıp kızmadığını sorduğunda dedesi; "Aksine, mutlu oldum. Kimse görmediği halde bana doğruyu söyledin." der. Sare de Allah gördüğ̈̈ için doğruyu söylediğini belirtir (4. bölümde üç kez). Sare ile dedesi arasında geçen bu diyalog öğretim programında bu değer kapsamında yer alan kazanımlardan "Ailesine her zaman dürüst davranır." ve "Dürüst olmanın Allah'ın sevdiği davranışlardan olduğunun farkına varır." kazanımlarını destekler niteliktedir. Dedesinin kendisine kızmayıp mutlu olması "Doğru ve dürüst olmanın olumlu sonuçlarını fark eder.”; Hz. Ömer döneminden aktarılan örnek olay da "Dürüst olan ve olmayan davranışları ayırt eder." ve "Çevresine karşı her zaman dürüst olur." kazanımlarını desteklemektedir. Yusuf'un Dünyasında ise doğruluk/dürüstlük değerine ilişkin olarak; tuvalete çıkmak için sınıf- 
tan dışarı çıkan ancak tuvalete gitmeyip abisinin sınıfına giden çocuğa evde bu konu görüşülünce annesi "Sınıftan çıkmak için tuvalete gideceğini söylemişsin, yani doğruyu söylememişsin." diyerek bunun hata olduğunu belirtir (4. bölüm). Bu içeriğin öğretim programında yer alan kazanımlardan herhangi birini doğrudan desteklemediği görülmüştür. Çizgi filmlerde doğruluk/dürüstlük değerine ilişkin sunulan içeriğin öğretim programında bu değer kapsamında yer alan dokuz kazanımdan beşi ile örtüştüğü ve içeriğin çoğunlukla çocukların bu değere ilişkin farkındalıklarını artırmaya ve ayırt etme bilişsel becerisine dönük olarak işlendiği görülmüştür.

Literatürde çizgi filmleri değerler açısından inceleyen çalışmalara bakıldığında doğruluk/dürüstlük değerine çizgi filmlerde görece farklı ağırlıklarda yer verildiği görülmektedir. Örneğin Niloya çizgi filminde bu değere direkt değil, örtülü olarak yer verildiği (Karakuş, 2015); Rafadan Tayfa'nın 40 bölümünde 20 değer içerisinde doğruluğa \%10 oranında yer verildiği (Sadioğlu vd., 2018); Doraemon çizgi filminde belirlenen 19 dini değer arasında \%19.64 oranla doğruluk/dürüstlük değerine ikinci sırada yoğunlukta yer verildiği (Cebeci ve Demir, 2018); Rafadan Tayfa'nın üç bölümünde dürüstlük değerine 21 değer arasında rastlanmadığı (Şahin, 2019); başka bir çalışmada da yine Rafadan Tayfa çizgi filminde belirlenen 10 evrensel değerden biri olarak dürüstlük değerine \%7.10 oranında yer verildiği sonucu ortaya konmuştur (Şentürk ve Keskin, 2019). Bu sonuçlarla karşılaştırıldığında Diyanet TV çizgi filmlerinde doğruluk/dürüstlük değerine nispeten sinırlı yer verildiği görülmektedir.

Örgün eğitimin öğretim programlarına bakıldığında dürüstlük değerinin de tüm dersler için belirlenen 10 kök değerden biri olduğu görülmektedir. Bunun yanı sıra yine çeşitli çalışmalarda öğretmen görüşlerine göre dürüstlük öncelikli olarak yer verilmesi gereken ilk üç değerden biri olarak gösterilmiştir (Balc1 ve Yanpar Yelken, 2013; Arpac1, 2014; Ünlü ve Kaşkaya, 2018; Kozikoğlu, 2018; Kılcan, 2020). Hayat Bilgisi dersi öğretim programında da bu değeri destekleyen açıklamalar bulunmaktadır (Okul Öncesi Eğitim Programı, 2013, s. 28; Hayat Bilgisi Dersi Öğretim Programı, 2018, s. 19). Bu önemine karş1lı çizgi filmlerde bu temel değere sınırlı bir kapsamda yer verilmiş olduğu tespit edilmiştir.

\section{İyilik Değerine İlişkin Bulgular}

Esasında pek çok olumlu değerin bir yönüyle iyilik kapsamında olduğu düşünülebilir. Ancak 4-6 Yaş Grubu Kur'an Kursları Öğretim Programında iyilik ayrı bir değer olarak geçtiği ve bu kapsamda yedi kazanıma yer verildiği 
için bu çalışmada da müstakil olarak analiz kapsamına alınmıştır. Fakat yapılan analizlerde bu değere her iki çizgi filmde de doğrudan yer verilmediği görülmüştür. Benzer şekilde çizgi filmleri değerler açısından analiz eden literatüre iyilik değeri özelinde bakıldığında da bu değerin ayrı bir kategoride çoğunlukla geçmediği görülmüşsür. Tespit edildiği kadarıyla yalnızca bir çalışmada, Niloya çizgi filminde iyilik değerinin her bölümde yer alan, çizgi filmde en sık işlenen değerlerden biri olduğu sonucu ortaya konulmuştur (Karakuş, 2015). Bu sınır11 içeriğe karşılık esasında çizgi filmlerde iyilik değerinin; günlük hayatta iyilik olarak nitelendirilebilecek davranışların örneklendirilerek işlenmesi, iyilik yapmanın Allah'ın sevdiği davranışlardan olduğu, iyiliğin karşılık beklemeden yapılabilecek ve insanın hayatını olumlu etkileyecek bir değer olduğu gibi bağlamlarda ele alınması mümkündür. Bu sayede çocukların, tüm değerlerin yanı sıra çeşitli şekillerde iyi davranışlar ortaya koymaya ve iyiliksever bir insan olmanın kazandırdıklarına aşina kılınması sağlanabilir.

\section{Merhamet/Şefkat Değerine İlişkin Bulgular}

Çizgi filmlerde merhamet/şefkat değerine yer verilme durumu Tablo 4 'te gösterilmiştir.

\begin{tabular}{lll}
\hline Tablo 4: Çizgi Filmlerde Merhamet/Ş̧efkat Değerine Yer Verilme Durumu \\
\hline Merhamet/Şefkat Değeri & $\begin{array}{l}\text { Değere Çizgi Filmde Yer Verilme } \\
\text { Sıklığı }\end{array}$ & $\begin{array}{l}\text { Değere Yer Verilen Bölüm } \\
\text { No }\end{array}$ \\
\hline Dedemin Öyküleri & 1 & 1 \\
\hline Yusuf'un Dünyası & - & - \\
\hline
\end{tabular}

Merhamet/şefkat değerinin Dedemin Öyküleri çizgi filminde bir kez geçtiği; Yusuf'un Dünyasında ise bu değere hiç yer verilmediği görülmektedir.

Dedemin Öykülerinde bir kez yer verilen merhamet/şefkat değeri hayvanlara yönelik merhamet bağlamında işlenmektedir. Tüm aile, ayağı yaralanan kuzunun ayağını merhem sürerek sarar. Bunun üzerine dede, Hz. Muhammed'in kalabalık bir orduyla sefere çıkmışken yeni doğum yapmış köpek ve yavrularını görmesi ve ordunun, köpek ve yavrularını ezmemesi için bunu önlemek üzere birkaç kişiyi görevlendirmesi, böylece onları uyandırmadan yanlarından geçip gitmelerine ilişkin örnek olayı anlatır (1. bölüm). Bu çizgi filmde sunulan içerik, öğretim programında bu değer kapsamında yer alan dört kazanımdan "Çevresindeki varlıklara merhamet gösterir." kazanımını destekler niteliktedir.

Literatürde çizgi filmleri değerler açısından inceleyen çalışmalara bakıldığında merhamet değerinin her çalışmada kategori olarak alınmadığı, alınan çizgi film- 
lerde de bu değere görece farklı ağıllıklarda yer verildiği görülmektedir. Bu çalışmalara bakılacak olursa; Doraemon çizgi filminde merhamet değerinin 19 dini değer içinde yedi kez geçtiği, Rafadan Tayfa çizgi filminde ise yine 19 dini değerden biri olarak 13 kez yer aldığı (Cebeci ve Demir, 2018); başka bir çalışmada Rafadan Tayfa çizgi filminin 40 bölümünde 20 değer içerisinde merhamete \%7.5 oranında yer verildiği (Sadioğlu vd., 2018); farklı bir çalışmada yine Rafadan Tayfa çizgi filminin üç bölümünde merhamet değerinin 21 değer içinde bir kez geçtiği, Arı Maya çizgi filminde ise yine 21 değer içinde 11 kez yer verilen en sık değerlerden biri olduğu (Şahin, 2019) sonuçları ortaya konulmuştur.

Merhamet, Milli Eğitim Bakanlığı tarafindan belirlenen 10 kök değerden biri olmasa da bazı çalışmalarda öğretmenlerin kök değerler arasında yer almasını belirttiği değerlerden biridir (Kılcan, 2020). 4-6 Yaş Grubu Kur'an Kursları Öğretim Programında yer verilen kazanımlara bakıldığında da merhamet değerinin; çeşitli varlıklara yönelik merhamet, Allah'ın tüm varlıklara yönelik merhameti, merhametin Allah'ın sevdiği davranışlardan biri olduğu ve merhamet davranışının olumlu sonuçlarının fark edilmesi gibi geniş bir bağlamda ele alındığı görülmektedir. Bu çerçeve de dikkate alındığında çizgi filmlerde bu değere ilişkin verilen içeriğin oldukça yetersiz olduğu belirtilmelidir.

\section{Özür Dileme Değerine İlişkin Bulgular}

Çizgi filmlerde özür dileme değerine yer verilme durumu Tablo 5 'te gösterilmiştir.

\begin{tabular}{lll}
\hline \multicolumn{1}{l}{ Tablo 5: Çizgi Filmlerde Özür Dileme Değerine Yer Verilme Durumu } \\
\hline Özür Dileme Değeri & $\begin{array}{l}\text { Değere Çizgi Filmde Yer Veril- } \\
\text { me Siklığ1 }\end{array}$ & $\begin{array}{l}\text { Değere Yer Verilen Bölüm } \\
\text { No }\end{array}$ \\
\hline Dedemin Öyküleri & 3 & $2,4,9$ \\
\hline Yusuf'un Dünyası & 13 & $2,3,4,8$ \\
\hline
\end{tabular}

Özür dileme değerinin Dedemin Öyküleri çizgi filminde üç, Yusuf'un Dünya$s i n d a$ ise 13 kez geçtiği görülmektedir.

Dedemin Öykülerinde bu değer; torunun, "Özür dilerim dedeciğim, sabredemedim ben." demesi (2. bölüm); koşarken kuzuya çarpan çocuğun kuzudan özür dilemesi (4. bölüm); yarışta arkadaşına haksızlık ettiğini düşünen çocuğun "Galiba Ali’ye haksızlık ettim, özür dilerim.” (9. bölüm) demesi şeklinde günlük hayat akışı içinde kişiler arası ilişkiler bağlamında geçmektedir. Dedemin Öykülerinde ise; sınavda, bunun yanlış olduğunu bilmeden kopya çeken iki öğrenciye öğretmenleri kızınca öğretmenden özür dilerler (2. bölümde iki kez). Bir sonraki bölümde sınıfta ders esnasında kendisi dışarıdan çağrılan öğrenci, 
sınıftan çıkmak için “Özür dilerim öğretmenim, izin verir misiniz?” der. Annesi, arkadaşının yüzünü boya kalemiyle çizen çocuğundan ertesi gün arkadaşından özür dilemesini ister. Çocuk buna mecbur olup olmadığını sorduğunda, annesi "Evet” der. Çocuk ertesi gün arkadaşından özür diler. Dışarıdan sınıfa girmek isteyen öğrenci öğretmenden özür dileyerek içeri girer (3. bölümde altı kez). Sonraki bölümde çocuk, eve geldiğinde annesi ona arkadaşından özür dileyip dilemediğini sorar ve anne burada özür dilemeyi açıklar: "Özür dilemenin anlamı, aynı şeyi bir daha yapmayacağına söz vermektir." "Özrü kabul etmenin karşıllığı da 'aynı şeyi bir daha yapma', olmalıdır (4. bölümde dört kez). Bu bağlam dışında özür dilemek değeri bir kez de seccade ile kedi arasında geçen bir diyalogda seccadenin kediden özür dilemesi şeklinde geçmektedir (8. bölüm). Her iki çizgi filmde yer verilen bu içeriğin öğretim programında bu kapsamda yer verilen dört kazanımdan "Özür dileme ile ilgili ifadeleri kullanır." ve "Hata yaptı̆̆ında özür diler.” kazanımlarını desteklediği görülmektedir.

Çizgi filmleri değerler açısından analiz eden literatüre özür dilemek değeri özelinde bakıldığında; özür dilemenin ayrı bir analiz kategorisi olarak ele alınmadığı görülmektedir. Ancak özür dilemek ve teşekkür etmek okul öncesi dönem çocuğunun sosyal gelişimi açısından temel kazanımlardır. Nitekim okul öncesi eğitimi öğretim programında yer alan "Değişik ortamlardaki kurallara uyar." kazanımının açıklamasına bakıldığında da çocukların toplumsal yaşamın devam ettirilmesi için gerekli olan görgü kurallarından biri olarak da özür dilemeye uygun davranmasının hedeflendiği; yine Hayat Bilgisi dersi öğretim programında da bunu destekleyen bir kazanımın yer aldığı görülmektedir (Okul Öncesi Eğitim Program1, 2013, s. 29; Hayat Bilgisi Dersi Öğretim Program1, 2018, s. 13). Bu doğrultuda çizgi filmlerde bu temel değere yetişkinlerin yanı sıra bizzat çocuk kahramanların dilinden de yer verilmesinin izleyici hedef kitlenin modelleyerek öğrenmesi açısından olumlu olduğu düşünülmektedir.

\section{Sabır Değerine İlişkin Bulgular}

Çizgi filmlerde sabır değerine yer verilme durumu Tablo 6'da gösterilmiştir.

Tablo 6: Çizgi Filmlerde Sabır Değerine Yer Verilme Durumu

\begin{tabular}{lll}
\hline Sabır Değeri & $\begin{array}{l}\text { Değere Çizgi Filmde Yer Verilme } \\
\text { Siklığı }\end{array}$ & $\begin{array}{l}\text { Değere Yer Verilen Bölüm } \\
\text { No }\end{array}$ \\
\hline Dedemin Öyküleri & 5 & 2,7 \\
\hline Yusuf'un Dünyası & 1 & 6 \\
\hline
\end{tabular}


Sabır değerinin Dedemin Öyküleri çizgi filminde beş, Yusuf'un Dünyasında ise bir kez geçtiği görülmektedir.

Sabır değeri Dedemin Öykülerinde Sabretmek bölümünde darı tohumu eken Sare'nin, tohumun hemen yeşerip sebze vermesini beklemesi örneği üzerinden işlenmektedir. Sare, dedesine mısırların ne zaman büyüyeceğini sorar, dedesi de; "Güzel kızım biraz sabret, çok kısa zamanda yeşerirler." der. Aradan bir süre geçer, mısırların başında büyümesini bekleyen Sare sabredemez. Bunun üzerine dedeleri de "Siz Hz. Yakup'un sabrını duydunuz mu?" diyerek Hz. Yakup'un oğlu Hz. Yusuf'un kaybolması üzerine sabretmesi kıssasını anlatır ve "Sabrın sonu selamettir." atasözüne yer verir (2. bölümde dört kez). Başka bir bölümde ise balık tutmayı deneyen çocuğa dedesinin "Balık tutmak sabır işi, biraz beklemelisin.” (7. bölüm) demesi şeklinde kullanılmaktadır. Sabır değeri Dedemin Öykülerinde ise ney üflemeye çalışan çocuğun ses çıkaramayınca dedesinin ona "Sabırlı ol." demesi şeklinde geçmektedir (6. bölüm). Çizgi filmlerde sunulan içerik öğretim programında sabır değeri kapsamında yer alan yedi kazanım açısından değerlendirilecek olursa iki çizgi filmde de balık tutmak, ney üflemek, tohumun hemen meyve vermesine ilişkin içeriklerin, "Sabırlı olmayı gerektiren durumlara örnekler verir." ve "İsteklerini ertelemesini bilir." kazanımlarını; "Sabrın sonu selamettir." atasözü ise "Sabırlı olmanın olumlu sonuçlarını fark eder." kazanımını desteklediği söylenebilir. Çizgi filmlerde sabır değerinin yalnızca bilişsel boyutta ele alınmayıp bizzat çocuğun yaşamından örneklendirilerek somutlaştırılması, değeri çocuğun gözünde anlaşılır ve ikna edici kılması ve duyuşsal etki uyandırması bakımından dikkat çekicidir.

Çizgi filmleri değerler açısından analiz eden literatüre bakıldığında sabır değerinin analiz kategorisi olarak alındığı çalışmaların az sayıda olduğu görülmüştür. Bunlardan Dede Korkut çizgi filminde sabır duygusunu geliştirici iletiler olduğu (Yaman vd., 2015); Rafadan Tayfa'nın 40 bölümünde 20 değer içerisinde sabır değerine \%15 oranında yer verildiği (Sadioğlu vd., 2018); başka bir çalışmada da yine Rafadan Tayfa'da belirlenen 19 dini değerden biri olarak sabır değerine sınırlı yer verildiği, Doraemon'da ise yer verilmediği görülmüştür (Cebeci ve Demir, 2018).

Sabır değeri de örgün eğitimde tüm dersler için belirlenen 10 kök değerden biridir. Ancak gerek okul öncesi eğitimi gerekse Hayat Bilgisi dersi öğretim programlarında sabır değerine müstakil olarak yer verilmemektedir. Bununla birlikte her iki öğretim programında da istek ve ihtiyaçlar bağlamında yer verilen içerik bu değerle ilintili olarak görülebilir. Bunun yanı sıra Hayat Bilgisi 
dersi öğretim programında "Sınıfta ve okulda yapılan etkinliklerde grupla çalı̧̧ma kurallarına uyar." kazanımı işlenirken konu çerçevesinde sabır değerinin de ele alınması gerektiği belirtilmektedir (Hayat Bilgisi Dersi Öğretim Programı, 2018). Çocukların, isteklerini kontrol edebilme veya erteleme becerisine henüz sahip olmadıkları düşünüldüğünde gerek çeşitli derslerin öğretim programlarında gerekse çizgi filmlerde sabır değerine çocukların gelişim düzeyi ve tecrübesine uygun içeriklerle yer verilmesinin yararlı olacağı belirtilmelidir. Bu değere 4-6 Yaş Grubu Kur'an Kursları Öğretim Programında ayrı bir ünitede yer verilmesi ve bu kapsamın gerek duyuşsal gerekse bilişsel boyuttaki kazanımlarla ele alınması programın önemli bir boşluğa yönelik ihtiyacı doldurması bakımından ayırt edici yönünü göstermektedir.

\section{Saygı Değerine İlişkin Bulgular}

Çizgi filmlerde saygı değerine yer verilme durumu Tablo 7'de gösterilmiştir.

\begin{tabular}{lll}
\hline \multicolumn{2}{l}{ Tablo 7: Çizgi Filmlerde Saygı Değerine Yer Verilme Durumu } \\
\hline \multirow{2}{*}{ Saygı Değeri } & $\begin{array}{c}\text { Değere Çizgi Filmde Yer Verilme } \\
\text { Sıklığı }\end{array}$ & $\begin{array}{l}\text { Değere Yer Verilen Bölüm } \\
\text { No }\end{array}$ \\
\hline Dedemin Öyküleri & - & - \\
\hline Yusuf'un Dünyası & 2 & 10 \\
\hline
\end{tabular}

Sayg1 değerine Dedemin Öyküleri çizgi filminde yer verilmediği, Yusuf'un Dünyasında ise iki kez yer verildiği görülmektedir.

Yusuf'un Dünyasında bu değer; kendisine hediye verilen çocuğun, hediye paketini yırtarak açmanın hediye verene saygısızlık olduğunu düşündüğünü belirtmesi, kuzeninin de bunu kendisine yapılmış saygısızlık olarak anlamayacağını söylemesi şeklinde tek bağlamda geçmektedir (10. bölümde iki kez).

Çizgi filmlerde saygı değerine ilişkin sınırlı içeriğe karşılık öğretim programında bu değer kapsamında 12 kazanıma yer verildiği görülmektedir. $\mathrm{Bu}$ kapsamda saygı değerinin; Allah'a, Peygambere, Kur'an-1 Kerim'e, aileye, arkadaşlara ve çevreye saygı başlıklarında detaylandırıldığı; saygı ile ilgili ifadelerin kullanılması, saygı davranışının olumlu sonuçlarının fark edilmesi, saygılı olmanın Allah'ın sevdiği davranışlardan biri olması gibi bağlamlara da yer verildiği görülmektedir. Çizgi filmde yer verilen içeriğin, bu kazanımlardan "Çevresine karşı saygılı davranır." kazanımını destekler doğrultuda olduğu söylenebilir.

Çizgi filmleri değerler açısından analiz eden literatüre saygı değeri özelinde bakıldığında; Niloya çizgi filminin 18 bölümünde 22 değer içerisinde sayg1 
değerinin 10 kez geçtiği (Karakuş, 2015); Dede Korkut'tun incelenen tüm bölümlerinde saygı duygusunu geliştirici iletiler olduğu (Yaman vd., 2015); Küçük Hezarfen çizgi filminde saygı değerine 21 değerden içerisinde $\% 6.97$ oranında yer verildiği (Selanik Ay ve Korkmaz, 2017); Rafadan Tayfa çizgi filminin 40 bölümünde 20 değer içerisinde saygı değerine \%7.5 oranında yer verildiği (Sadioğlu vd., 2018); başka bir çalışmada Rafadan Tayfa ve Arı Maya çizgi filmlerinde saygının en sık yer verilen değerlerden biri olduğu (Şahin, 2019); yine Rafadan Tayfa çizgi filmini inceleyen farklı bir çalışmada da saygı değerinin en sık işlenen değerlerden biri olduğu ortaya konulmuştur (Şentürk ve Keskin, 2019). Diğer çizgi filmlerle kıyaslandığında Diyanet TV çizgi filmlerinde saygıya verilen yerin oldukça sınırlı olduğu görülmektedir.

Örgün eğitimin öğretim programlarında 10 kök değerden biri olarak belirlenmiş olan saygı, en temel değerlerden biridir. Bunun yanı sıra okul öncesi eğitimi öğretim programında da bu dönemde çocukların saygı davranışı geliştirmesinin okul öncesi eğitimin temel ilkelerinden biri olarak belirtildiği görülmektedir (Okul Öncesi Eğitim Programı, 2013, s. 11). Aynı programda ve Hayat Bilgisi dersi öğretim programında saygı değerine ilişkin kazanımlar yer almakta; fark11 kazanımların açıklamaları kapsamında da saygı değerinin dikkate alınması gerekliliği dikkat çekmektedir. (Hayat Bilgisi Dersi Öğretim Programı, 2018).

Literatürde değerlerin önemi ve önceliğinin incelendiği çeşitli çalışmalara bakıldığında da saygı değerinin öğretmenler tarafından kazandırılması öncelikli görülen üç değerden biri olarak gösterildiği görülmektedir (Çengelci vd., 2013; Çelikkaya ve Filoğlu, 2014; Kozikoğlu, 2018; Kılcan, 2020.) Tüm değerler içerisindeki bu öncelikli yeri dikkate alındığında çizgi filmlerde de saygı değerine günlük yaşam içerisinde verilen yerin artırılmasının gerekli olduğu düşünülmektedir.

\section{Sevgi Değerine İlişkin Bulgular}

Çizgi filmlerde sevgi değerine yer verilme durumu Tablo 8'de gösterilmiştir.

Tablo 8: Çizgi Filmlerde Sevgi Değerine Yer Verilme Durumu

\begin{tabular}{lll}
\hline Sevgi Değeri & $\begin{array}{l}\text { Değere Çizgi Filmde Yer Verilme } \\
\text { Siklığı }\end{array}$ & $\begin{array}{l}\text { Değere Yer Verilen Bölüm } \\
\text { No }\end{array}$ \\
\hline Dedemin Öyküleri & 3 & $1,5,10$ \\
\hline Yusuf'un Dünyası & 3 & 2,10 \\
\hline
\end{tabular}


Sevgi değerinin her iki çizgi filmde de üçer kez geçtiği görülmektedir.

Dedemin Öykülerinde bu değer, ikisi Allah'ın kullarını sevmesi, biri de hayvan sevgisi bağlamında geçmektedir. Dedenin; "Hayır yapılmasına aracı olan hayrı yapmış kadar Allah tarafından sevilir." (5. bölüm), "Allah işini iyi yapanları sever." (10. bölüm) ve Sare'nin "Hayvanları çok sevmeliyiz." ifadelerinde bu değere yer verilmiştir (1. bölüm). Yusuf'un Dünyasında ise Resim dersinde kedisini resmeden öğrencinin resmini öğretmeninin beğenmesi ve "Sevgini çok güzel anlatmışsın." demesi (2. bölüm); abinin kardeşine "Ben seni çok seviyorum.", kardeşinin de "Ben de seni seviyorum." demesi şeklinde kullanılmaktadır (10. bölümde iki kez). En temel değerlerden biri olan sevgi değerine çizgi filmlerde üçer kez yer verilmesine karşıllı öğretim programında bu kapsamda dokuz kazanımın olduğu görülmektedir. Çizgi filmlerde yer verilen içeriğin, bu kazanımlardan "Ailesine karşı sevgisini gösterir.", "Çevresindeki varlıkları sever.", "Sevgi ve merhamet göstermenin Allah'ın sevdiği davranışlardan olduğunun farkına varı." kazanımlarını desteklediği söylenebilir.

Çizgi filmleri değerler açısından analiz eden literatüre sevgi değeri özelinde bakıldığında; Niloya (Karakuş, 2015), Rafadan Tayfa ve Arı Maya (Şahin, 2019) ve yine Rafadan Tayfa (Şentürk ve Keskin, 2019) çizgi filmlerinde sevgi değerinin en sık yer verilen değerlerden olduğu; diğer bazı çalışmalarda da bu değere 20 değer içerisinde \%12.5 (Sadioğlu vd., 2018) ve 21 değer arasında \%7.90 oranlarında yer verildiği (Selanik Ay ve Korkmaz, 2017) görülmüştür. Diğer çizgi filmlerle karşılaştırıldığında Diyanet TV'de sevgi değerine verilen yerin oldukça kısıtlı olduğu görülmektedir.

Sevgi değeri de örgün eğitimin öğretim programları için belirlenmiş olan on kök değerden biridir. Bunun yanı sıra gerek okul öncesi eğitimi gerekse Hayat Bilgisi dersi öğretim programlarında farklı bağlamlarda yer verilen veya dikkat çekilen değerlerdendir (Okul Öncesi Eğitim Program1, 2013; Hayat Bilgisi Dersi Öğretim Program1, 2018). Yine literatürde öğretmen görüşlerine göre değerlerin önemi ve önceliğinin incelendiği çeşitli çalışmalarda sevgi değerinin en önemli görülen değerlerden biri olduğu sonucuna ulaşılmıştır (Balcı ve Yanpar Yelken, 2013; Çengelci vd., 2013; Arpacı, 2014; Ünlü ve Kaşkaya, 2018; Kozikoğlu, 2018; Kılcan, 2020). Bu önemi ve genel olarak insan yaşamında, özelde de bir çocuğun hayatındaki yeri dikkate alındığında çizgi filmlerde sevgi değerine daha fazla yer verilmesinin gerekliliği ortaya çıkmaktadır. 


\section{Sorumluluk Değerine İlişkin Bulgular}

Çizgi filmlerde sorumluluk değerine yer verilme durumu Tablo 9'da gösterilmiştir.

Tablo 9: Çizgi Filmlerde Sorumluluk Değerine Yer Verilme Durumu

\begin{tabular}{lll}
\hline Sorumluluk Değeri & $\begin{array}{l}\text { Değere Çizgi Filmde Yer Verilme } \\
\text { Siklığ } 1\end{array}$ & $\begin{array}{l}\text { Değere Yer Verilen Bölüm } \\
\text { No }\end{array}$ \\
\hline Dedemin Öyküleri & 1 & 6 \\
\hline Yusuf'un Dünyası & - & - \\
\hline
\end{tabular}

Sorumluluk değerine Dedemin Öyküleri çizgi filminde bir kez yer verildiği; Yusuf'un Dünyasında ise hiç yer verilmediği görülmektedir.

Sorumluluk değeri Dedemin Öykülerinde kendisine emanet edilen bir şeyi koruyamayan çocuğa dedesinin; "Verilen sorumluluğu özenle yerine getirmeli, siz elinizden gelenin en iyisini yapmaya çalışın.” demesi şeklinde geçmektedir (6. bölüm). Her iki çizgi filmde de toplamda sadece bir kez geçen sorumluluk değerine ilişkin öğretim programında 11 kazanım yer almaktadır. Çizgi filmde geçen bağlamın, "Çevreye karşı sorumluluklarını yerine getirir." kazanımını destekler doğrultuda olduğu söylenebilir.

Literatürde çizgi filmleri değerler açısından inceleyen çalışmalara bakıldı̆̆ında; Niloya (Karakuş, 2015); Dede Korkut (Yaman vd., 2015); Küçük Hezarfen (Selanik Ay ve Korkmaz, 2017); Rafadan Tayfa (Sadioğlu vd., 2018); Doraemon (Cebeci ve Demir, 2018); Rafadan Tayfa ve Arı Maya (Şahin, 2019) ve yine Rafadan Tayfa (Şentürk ve Keskin, 2019) gibi çeşitli çalışmalarda konu edilen çizgi filmlerde sorumluluk değerine görece farklı ağırlıklarda yer verildiği görülmektedir. Literatürle kıyaslandığında sorumluluk değerine, Diyanet TV çizgi filmlerinin izlenen bölümlerinde yalnızca bir kez sınırlı bir kapsamda yer verildiği belirtilmelidir.

Sorumluluk da örgün eğitimin öğretim programları için 10 kök değerden biri olarak belirlenmiştir. Bu değere okul öncesi eğitimi öğretim programında "Sorumluluklarını yerine getirir." kazanımı başta olmak üzere çeşitli bağlamlarda yer verildiği görülmektedir. Hayat Bilgisi dersi öğretim programında da "Evde, üzerine düşen görev ve sorumluluklarını fark eder.”, "Evde üzerine düşen görev ve sorumlulukları yerine getirir." ve "Doğa ve çevreyi koruma konusunda sorumluluk alır.” kazanımları çerçevesinde bu değere yer verilmiştir (Okul Öncesi Eğitim Programı, 2013; Hayat Bilgisi Dersi Öğretim Program1, 2018). Bu değerin erken çocukluk döneminden itibaren gelişmesi açısından çizgi filmlerde de çocukların da yaşam içerisinde çeşitli sorumluluklarının olduğunu fark etmesine dönük içeriklere yer verilmesinin yerinde olacağı belirtilmelidir. 


\section{Şükür/Teşekkür Değerine İlişkin Bulgular}

Çizgi filmlerde şükür/teşekkür değerine yer verilme durumu Tablo 10'da gösterilmiştir.

\begin{tabular}{lll}
\hline \multicolumn{2}{l}{ Tablo 10: Çizgi Filmlerde Şükür/Teşekkür Değerine Yer Verilme Durumu } \\
\hline Şükür/Teşekkür Değeri & $\begin{array}{l}\text { Değere Çizgi Filmde Yer Verilme } \\
\text { Siklığ1 }\end{array}$ & $\begin{array}{l}\text { Değere Yer Verilen Bölüm } \\
\text { No }\end{array}$ \\
\hline Dedemin Öyküleri & 3 & 2,7 \\
\hline Yusuf'un Dünyası & 13 & $2,3,4,5,8,9,10$ \\
\hline
\end{tabular}

Şükür/teşekkür değerinin Dedemin Öyküleri çizgi filminde üç, Yusuf'un Dünyasında ise 13 kez geçtĭgi görülmektedir.

Dedemin Öykülerinde şükür/teşekkür değeri ikisi Allah'a şükür, biri insanların birbirine teşekkürü olmak üzere üç kez geçmektedir. Bağlamlarına bakılacak olursa; Hz. Yakup'un oğlu Hz. Yusuf'a yıllar sonra yeniden kavuştuğu için şükretmesi (2. bölüm) ve balığın karnından çıkan Yunus Peygamber'in secdeye kapanıp Allaha şükretmesi (7. bölüm) örnekleri ile peygamberlerin Allah'a şükrü şeklinde yer verilmiştir. Bir kez geçen teşekkür değeri ise yakaladıkları küçük balığı suya geri bırakan çocuğa, arkadaşının; "Sare, küçük bir balık sana teşekkür etti." (7. bölüm) demesi şeklinde geçmektedir. Bu kapsamda kodlamaya dahil edilmemekle birlikte bazı bölümlerde teşekkür yerine "sağol" ifadesine yer verildiği de görülmüştür (6. ve 10. bölümler). Yusuf'un Dünyası çizgi filminde ise iki kez Allah'a şükür, 11 kez de insanlar arası teşekkür geçmektedir. Teşekkür değeri bağlamları şu şekildedir; öğretmen çocuğun resmini beğenip çok güzel çizdiğini söyleyince öğrenci teşekkür eder (2. bölüm); arkadaş1 özrünü kabul edince Osman teşekkür eder (3. bölüm); köpeğine mama veren Yusuf, köpek onun yüzünü yalayınca "Karabaş'ın teşekkürü de bu işte." der (4. bölüm). Elif, kuzenine yardıma ihtiyacı olup olmadığını sorduğunda kuzeni teşekkür eder; kuzenine namaz kılmadan önce başını nasıl örtmesi gerektiğini öğretince kuzeni kendisine teşekkür eder; Elif de kuzenine teşekkür eder; yengesi seccade verince yeğen teşekkür eder (8. bölümde dört kez). Kendilerine hediye verilen çocuklar kuzenlerine teşekkür eder (10. bölümde dört kez). Şükür ise iki kez baba kahramanın ifadelerinde "Çok şükür" (5. bölüm) ve herhangi bir bağlam olmaksızın kendi kendine "Sana şükürler olsun Allah'ım" (9. bölüm) sözleri ile kullanılmaktadır. Bunlar dışında kod olarak alınmamakla birlikte "sağol" ifadesinin de kullanıldığı görülmektedir (4., 5. ve 10. bölümler). Çizgi filmlerde diğer değerlere nazaran daha sık yer verilen bu değere ilişkin öğretim programında beş kazanım bulunmaktadır. Çizgi filmlerde yer verilen içeriklerin bunlardan "Şükür ile ilgili ifadeleri kullanır.", "Kendisine yapılan iyilikler için 
teşekkür eder." ve "Allah'ın verdiği nimetlere şükreder." kazanımlarını desteklediği görülmektedir.

Çizgi filmleri değerler açısından analiz eden literatüre şükür/teşekkür değeri özelinde bakıldığında; bu değerin çoğunlukla ayrı bir analiz kategorisi olarak alınmadığı görülmektedir. Yalnızca bir çalışmada şükür, 19 dini değerden biri olarak analiz kategorisine dahil edilmiş ve incelenen iki ayrı çizgi filmde bu kapsamda içerik tespit edilmemiştir (Cebeci ve Demir, 2018).

$\mathrm{Bu}$ çalışmada özür dilemek başlığı altında belirtildiği gibi teşekkür etmek de özellikle okul öncesi dönem çocuğunun sosyal gelişimi açısından temel kazanımlardan biridir. Nitekim okul öncesi eğitimi öğretim programındaki "Değişik ortamlardaki kurallara uyar." kazanımının açıklamasına bakıldığında da çocukların toplumsal yaşamın devam ettirilmesi için gerekli olan görgü kurallarından biri olarak da teşekkür ve rica etme gibi davranışlar sergilemesinin hedeflendiği görülmektedir (Okul Öncesi Eğitim Programı, 2013, s. 29). Bunun yanı sıra Hayat Bilgisi dersi öğretim programında yer alan "Okulda iletişim kurarken nezaket kurallarına uyar." kazanımının bağlamında da bu değerin gerekliliğine işaret edilmektedir (Hayat Bilgisi Dersi Öğretim Programı, 2018, s. 19). Bu doğrultuda, bir değer olarak teşekkür etmeye okul öncesi dönemi çocukları için, gündelik yaşamda yine çocuk kahramanların dilinden yer verilmesi, Diyanet TV çizgi filmlerinin başarılı yönlerinden biridir.

\section{Yardımlaşma Değerine İliş̧kin Bulgular}

Çizgi filmlerde yardımlaşma değerine yer verilme durumu Tablo 11'de gösterilmiştir.

Tablo 11: Çizgi Filmlerde Yardımlaşma Değerine Yer Verilme Durumu

\begin{tabular}{lll}
\hline Yardımlaşma Değeri & $\begin{array}{l}\text { Değere Çizgi Filmde Yer Verilme Değere Yer Verilen Bölüm } \\
\text { Sıklığı }\end{array}$ \\
\hline Dedemin Öyküleri & 13 & $3,5,6,7,10$ \\
\hline Yusuf'un Dünyası & 30 & $2,3,4,10$ \\
\hline
\end{tabular}

Yardımlaşma değerinin Dedemin Öyküleri çizgi filminde 13, Yusuf'un Dünyasında ise $30 \mathrm{kez}$ geçtiği görülmektedir.

Dedemin Öykülerinde yardımlaşma değeri Yardımlaşmak bölümünün teması olduğu için bu bölümde kapsamlı bir şekilde ele alınmaktadır. Bu bölümde yardımlaşma değeri, Sare'nin arıların balından alarak karıncalara yardım etmek istemesi üzerinden işlenir. Bunun üzerine dedesi "İhtiyacı olan her canlıya yar- 
dım etmeliyiz, ama tabiatın da kendi içinde bir düzeni var." açıklamasını yapar. Ardından dede ve torunları, komşularının üzüm bağına imeceye gider. Dede imeceyi; "Köyde hasat zamanında herkes birbirine yardım eder ki işler bir an önce bitsin." şeklinde açıklar. Çocuklar da üzüm toplayarak imeceye dahil olurlar. Sonra bağ sahibi, bir bağı hayır için ayırdığını söyler, yanına gelen ve muhtaç görünen bir kişiye bir sepet üzüm verir. Bu noktada çocukların dedesi bunun bir hayır ve sadaka olduğunu açıklar. Ardından Hz. Muhammed döneminde iki avuç hurma kazanan sahabenin bir avucunu "Allah yolunda kendinden daha zor durumda olanlara yardım etmek için” ayırdığına ilişkin örnek olayı anlatır. Torunu Cihan; "Tüm gece çalışıp kazandığı bir avuç hurmayı yardım etmek için mi vermiş?" diye sorar. Bunun üzerine Sare; "Yardımın azı çoğu olmaz.", Cihan da; "Kendinden daha yoksula nasıl yardım ederim diye düşünmelisin." der (5. bölümde sekiz kez). Bu bölümün dışında geçen yardımlaşma değeri; abisinin, kardeşi Sare'ye eve gidip ninesine yardım etmesini söylemesi (3. bölüm), değirmenci çocuğun dede ve torunlarına "İsterseniz siz de bana yardım edebilirsiniz.” demesi (6. bölüm), balığın karnındaki Yunus Peygamber'in, Allah'tan yardım istediğinin söylenmesi (7. bölüm), dedenin, torunlarına; "Yardım etmek istiyorsanız size görev!” deyip bahçedeki odunları sıralı şekilde dizmelerini istemesi (10. bölüm) ve çocukların Ali isimli arkadaşının, oyun oynadıktan sonra yaptıkları işte onlara yardım edeceğini söylemesi (10. bölüm) şeklinde günlük hayat akışı içerisindeki diyaloglarda geçmektedir. Yusuf'un Dünyasında ise Yardımlaşma bölümünde geniş bir şekilde bu konu işlenmektedir. Bu bölümde konu, sınava hazırlanmayan bir arkadaşına sınavda bunun kopya olduğunu düşünmeden yardım eden Yusuf üzerinden işlenir. Yusuf, sınavda arkadaşına yardım eder. Öğretmeni iki öğrenciye de kızarak birine yardım etmenin güzel bir davranış olduğunu, ancak bu yaptıklarının yardımlaşma olmadığını söyler ve yardım etmenin ne demek olduğunu yazma ödevi verir. Akşam Yusuf'un evinde bu konu detaylıca ele alınır. Annesi, kopyanın ve yardımlaşmanın ne olduğunu anlatır. Yusuf akşam yemeğinde de yardımlaşma konusunda herkesin fikrini almak üzere bu konuyu açar (2. bölümde $13 \mathrm{kez}$ ). Sonraki bölümde Yusuf, yardımlaşma konulu hazırladığı ödevi sınıf içinde okur. Bu ödevde yardımlaşmanın tanımını yaparak günlük hayattan yardımlaşmaya ilişkin çeşitli örnekler verir. Bu örneklerden bazısı şunlardır: Hastaya bir kase çorba götürmek, alışverişten dönen bir kimsenin poşetini taşımak, sıcak havalarda sokak hayvanlarına bir kap su bırakmak, sofra hazırlanırken bir tabak koymak, arkadaşımızla ders çalışmak. Bu noktada bir gün babasının yaptığına şahit olduğu askıda ekmek kültüründen de söz eder (3. bölümde $14 \mathrm{kez}$ ). Çizgi filmin diğer bölümlerinde 
geçen diğer durumlar da şunlardır; kardeşi çantayı taşımakta zorlanınca abisinin; "Sana yardım edeyim." demesi (4. bölüm); annesi oğluna "Masayı çıkarmama yardım eder misin?" demesi (4. bölüm); babasının, Yusuf'a; "Savaş olan ülkelerdeki çocuklar için bir şeyler yapabiliriz; yardım toplayıp göndererek onlara destek olabiliriz." demesi (10. bölüm).

Her iki çizgi filmde de en sık yer verilen değer olan yardımlaşmaya ilişkin öğretim programında dokuz kazanım yer almaktadır. Her iki çizgi filmde de geniş bir yer verilen yardımlaşma değerine ilişkin içeriklerin şu sekiz kazanımı desteklediği görülmüştür: "Aile bireylerine yardım eder.", "Arkadaşlarına yardım eder.", "Yardım edilmesi veya istenmesi gereken durumları bilir.", "Yardım gerektiren durumların farkına varır.", "İhtiyacı olduğunda yardım ister.", "Yardımlaşma ve paylaşmaya istekli olur.", "Yardımlaşmanın Allah'ın sevdiği davranışlardan olduğunun farkına varır.", "Yardımlaşmanın olumlu sonuçlarını fark eder." Bu içerikle ilgili değerin yalnızca bilişsel düzeyde ele alınmayıp duyuşsal hedeflerin de gözetildiği görülmektedir.

Çizgi filmleri değerler açısından analiz eden literatüre yardımlaşma değeri özelinde bakıldığında; Küçük Hezarfen (Selanik Ay ve Korkmaz, 2017); Rafadan Tayfa (Sadioğlu vd., 2018) ve Arı Maya ve Rafadan Tayfa (Şahin, 2019) çizgi filmlerinde yardımlaşmanın en sik yer verilen değerlerden biri olduğu; Dede Korkut'ta yardımseverlik duygusunu geliştirici iletiler olduğu (Yaman vd., 2015); Doraemon ve Rafadan Tayfa çizgi filmlerinde yardımlaşma değerine farklı kapsamlarda yer verildiği (Cebeci ve Demir, 2018); Rafadan Tayfa çizgi filmini inceleyen farklı bir çalışmada ise bu değerin en az işlenen değerlerden biri olduğu (Şentürk ve Keskin, 2019) sonuçları ortaya konulmuştur. Yardımlaşmanın genel itibariyle birçok çizgi filmde en sık yer verilen değerlerden birisi olduğu, bu durumun Diyanet TV çizgi filmleri için de geçerli olduğu gözlenmiştir.

Yardımseverlik de örgün eğitimin öğretim programları için belirlenen 10 kök değerden biridir. Bunun yanı sıra okul öncesi dönemde çocukların yardımlaşma, dayanışma ve paylaşma gibi değer davranışlarının geliştirilmesi okul öncesi eğitiminin temel ilkelerindendir (Okul Öncesi Eğitim Program1, 2013, s. 11). Bu kapsamda bu temel değere her iki çizgi filmde de çeşitli bağlamlarda gerek duyuşsal gerekse bilişsel boyutlarda yer verilmesinin, Diyanet TV çizgi filmlerinin başarılı yönlerinden birisi olduğu tespit edilmiştir.

Her değere ilişkin bulguları ayrı başlıklar halinde ortaya koyduktan sonra çizgi filmlerde tüm değerlere yer verilme sıklı̆̆ gösterilmiştir. 


\begin{tabular}{lll}
\hline Tablo 12: Çizgi Filmlerde Tüm Değerlere Yer Verilme Siklı̆̆1 \\
\hline Değer & Dedemin Öyküleri & Yusuf'un Dünyast \\
\hline Adalet & 2 & - \\
\hline Doğruluk/Dürüstlük & 3 & 1 \\
\hline İyilik & - & - \\
\hline Merhamet/Şefkat & 1 & - \\
\hline Özür Dileme & 3 & 13 \\
\hline Sabır & 5 & 1 \\
\hline Sayg1 & - & 2 \\
\hline Sevgi & 3 & 3 \\
\hline Sorumluluk & 1 & - \\
\hline Şükür/Teşekkür & 3 & 13 \\
\hline Yardımlaşma & 13 & 30 \\
\hline Toplam & 34 & 63 \\
\hline
\end{tabular}

Tabloda görüleceği üzere her iki çizgi filmde de ortak yön olarak en sık yer verilen değerler yardımlaşma, özür dileme ve şükür/teşekkür; hiç yer verilmeyen değer ise iyiliktir. Diğer değerlere yer verilme durumunun ise iki çizgi filmde görece farklı olduğu görülmektedir. Analiz kategorisi olarak belirlenen 11 değere Dedemin Öykülerinin çeşitli bölümlerinde toplam 34 kez; Yusuf'un Dünyasında ise $63 \mathrm{kez}$ yer verildiği tespit edilmiştir.

\section{Sonuç ve Tartışma}

Genel olarak çizgi filmlerin, özelde de Diyanet TV çizgi filmlerinin her ne kadar değerleri kazandırma gibi bir yayın misyonu belirlenmiş olmasa da kitle iletişim araçlarının insanlar, özelde de çocuklar üzerinde birçok bakımdan şekillendirici rolü olduğu düşüncesiyle bu çalışmada çizgi filmler değerler açısından incelenmiştir. Bu bağlamda çalışmanın sonuç ve önerileri şu şekilde ifade edilebilir:

Öncelikle değerlerin işleniş bağlamı açısından yardımlaşma, sabır, adalet ve sorumluluk değerleri örneğinde konunun çocukların kendi gündelik yaşamından hareketle ele alındığg görülmektedir. Bu durum, gerek öğretimde hayatilik ilkesi gerekse ilgili değerin çocuğun yaşamı ve tecrübesine göre somutlaştırılması açısından uygunluk arz etmektedir. Yine bu noktada ilgili değer davranışını bizzat çizgi film kahramanı çocukların tatbik etmesinin, izleyici çocuk kitle üzerinde modelleyerek öğrenmede etkili olacağı söylenebilir.

Farklı bir nokta; yardımlaşma ve adalet değer örneklerinde; çocuğun ilgili kavramı/değeri yanlış anlaması üzerine; olması gerekenin yetişkinler tarafindan 
açıklanarak ele alınmasıdır. Konuların bu şekilde işlenmesinin çocuklar açısından etkili ve anlamlı öğrenme sağlayacağı söylenebilir.

Bir başka husus; bazı değerlerin ele alınışında dilimiz, kültürümüz veya dinimizden kavramlara yer verilmiş olmasıdır. Yardımlaşma konusunda imece ve askıda ekmek, sabır konusunda bir atasözü, yardımlaşma konusunda hayır ve sadaka kavramlarına yer verilmesi bu duruma ilişkin çeşitli örneklerdir. Bu boyutlar, çocukların, ilgili değerin dini ve kültürel yönlerine aşina kı1ınmaları açısından önemlidir.

Özellikle Dedemin Öykülerinde, çizgi filmin kurgusu gereği konu üzerine dede, peygamberlerin hayatı başta olmak üzere çeşitli öyküler anlatmakta, hikayenin akışında çocukların düşünmesine yönelik sorular sormakta, bu bağlamda hikayeleri örnek olay olarak kullanmaktadır. Bu yöntem, ilgili değerin bir örnek olay eşliğinde pekiştirilmesi ve ayrıca değere ilişkin olarak peygamberlerin rol model gösterilmesi açısından yerindedir.

Sıkça yer verilen özür dilemek ve teşekkür etmek değerlerine günlük hayatın akışı içerisinde gerek yetişkinlerin gerekse çocuk kahramanların dilinden yer verilmesi, okul öncesi ve okul dönemi çocuklarının en temel sosyal katılım becerisini ve görgü kurallarını edinmesine katkı sunması açısından çizgi filmlerin başarılı bir yönüdür. Bununla birlikte çizgi filmde birbiri ile iletişim halinde olan kişi sayısı ve diyaloglar düşünüldüğünde özür dilemek ve teşekkür etmek değerlerine daha sık bir şekilde yer verilmesinin mümkün olduğu belirtilmelidir. Bunun yanı sıra afedersin/iz, kusura bakma/yın gibi özür belirten alternatif sözcüklere yer verilmesi de çeşitli durumlarda farklı ifadelerin tercih edilebileceğinin örneklendirilmesi ve ayrıca çocukların dil ve sözcük dağarc1ğının gelişimi açısından uygun olacaktır. Teşekkürün yanı sıra Allah'a şükür ise daha ziyade peygamberlerin Allah'a şükretmesi veya aile büyüklerinin şükür ifadeleri şeklinde kullanılmaktadır. Oysa çocuk kahramanların dilinden de şükür değerine yer verilmesi izleyici çocuklar için örneklik teşkil edecektir.

En temel değerler olarak bilinen sevgi ve saygı değerlerine her iki çizgi filmde de oldukça kısıtlı yer verilmesi olumsuz bir sonuç olarak dikkat çekmiştir. Benzer şekilde adalet, doğruluk/dürüstlük, merhamet/şefkat ve sorumluluk değerlerinin de oldukça sınırlı kapsamda geçtiği görülmektedir. Oysa örgün eğitim için de 10 kök değerden altısı olarak belirlenen adalet, dürüstlük, sabır, saygı, sevgi, sorumluluk değerleri -bu makalede de yer verildiği gibi- çeşitli çalışmalarda öğretmenler tarafından en temel ve öncelikli değerler arasında gösterilmiştir. Bu doğrultuda çocuklarda kazandırılması beklenen bu temel değerlere 
çizgi filmlerde daha fazla yer verilmesi önerilebilir. Bu noktada çizgi filmleri değerler içeriği açısından zenginleştirirken 4-6 yaş grubu Kur'an kursu öğretim programından yararlanılabilir. Zira programda gerek bilişsel gerekse duyuşsal alanlar başta olmak üzere farklı öğrenme alanı ve düzeylerine; bunun yanı sıra ilgili değerin dinimizde önemli bir yeri olduğu, Allah'ın sevdiği davranışlardan olduğu ve bu değer doğrultusunda davranmanın olumlu sonuçları olduğu gibi muhteva açısından da zengin bir bağlam sunulmaktadır. Böylece bu değerleri çocuk kitlenin erken çocukluk döneminden itibaren fark etmesi, ayırt etmesi, örneklendirmesi ve bu doğrultuda yaşamaya istek duyması gibi kazanımların edinilmesine katkı sunacağı düşünülmektedir.

Bazı değerler (Merhamet, Sabretmek, Dürüstlük, Yardımlaşmak, Adaletli Olmak gibi) çizgi filmlerde müstakil bölümlerde işlenmektedir. Ancak bu bölümlerde ilgili değerlerin işleniş kapsam veya derinliği birbirinden farklıdır. Örneğin bizzat ilgili değerin adını taşıyan bazı bölümlerde adı geçen değerin kavram olarak yalnızca bir kez geçtiği bazen de derinlemesine ele alındığı görülmüştür. Bunun yerine değerlere çeşitli bölümlerde farklı bağlamlarda, günlük hayatın olağan akışı içerisinde yer verilerek çocukların ilgili değere ilişkin algı ve anlayışlarının pekiştirilmesi sağlanabilir.

Analiz kategorisinde yer almadığı halde her iki çizgi filmde de paylaşmak ve hayvan sevgisi değerlerinin sıkça işlendiği görülmüştür. Kedi, köpek, kuş ve kuzu başta olmak üzere pek çok hayvan, çocukların oyun arkadaşı olarak işlenmiştir. Bu da, çizgi filmlerin başarılı olduğu yönlerden biri olup ilgili değerler 4-6 Yaş Grubu Kur'an Kursu Öğretim Programına eklenebilir.

Farklı çalışmalarda Diyanet TV çizgi filmleri farklı değer kategorileri çerçevesinde ve görsel içerikler, alt mesajlar, örtük veya yan anlamlar açısından analiz edilebilir.

\section{Kaynakça}

Arpacı, M. (2014). Öğretmen ve velilerin İDKAB dersinde değerler ve değerler eğitimi hakkındaki görüşleri: Diyarbakır örneği. Marife, 14(2), 107-121.

Arslan, M. (2016). Kitle iletişim araçları, medya ve din ilişkisi üzerine. Birey ve Toplum Sosyal Bilimler Dergisi, 6(11), 5-25.

Bal, H. (2013). Nitel araştırma yöntemi. Fakülte Kitabevi.

Balcı, F. A ve Yanpar Yelken, T. (2013). İlköğretim sosyal bilgiler programında yer alan değerler ve değer eğitimi uygulamaları konusunda öğretmen görüşleri. 
Diyanet TV Çizgi Filmlerinin 4-6 Yaş Grubu Kur'an Kursu Öğretim Programinda Yer Alan Değerler ...

Ahi Evran Üniversitesi Kırşehir Eğitim Fakültesi Dergisi (KEFAD), 14(1), 195-213.

Büyükbaykal, G. (2007). Televizyonun çocuklar üzerindeki etkileri. Ístanbul Üniversitesi Illetişim Fakültesi Dergisi, 0(28), 31-44.

Cebeci, S. ve Demir, R. (2018). Çizgi filmler çocuklara neyi vaat ediyor?. Diyanet İlmi Dergi 54(1), 139-169.

Çelikkaya, T. ve Filoğlu, S. (2014). Sosyal bilgiler öğretmenlerinin değere ve değer eğitimine ilişkin görüşleri. Kuram ve Uygulamada Eğitim Bilimleri, 14(4), 1541-1556.

Çengelci, T., Hanc1, B. ve Karaduman, H. (2013). Okul ortamında değerler eğitimi konusunda öğretmen ve öğrenci görüşleri. Değerler Eğitimi Dergisi, 11(25), $33-56$.

Diyanet İşleri Başkanlığı. (2018). Kur'an kursları öğretim programı (4-6 yaş grubu). https://egitimhizmetleri.diyanet.gov.tr/Documents/Kur'an\%20 Kurslar\%C4\%B1\%20\%C3\%96\%C4\%9Fretim\%20Program\%C4\%B1\%20 (4-6\%20Ya\%C5\%9F\%20Grubu)\%202018.pdf).

Diyanet İşleri Başkanlığı. (2018). Dini yayınlar genel müdürlüğü. https://diniyayinlar.diyanet.gov.tr/sayfa/51/ilkeler-ve-hedefler.

Diyanet TV. (2020). Çocuk. https://www.diyanet.tv/cocuk.

Furat, A. Z. (2009). Yaygın din eğitiminde kitle iletişim araçlarının yeri: Televizyon örneği. İstanbul Üniversitesi İlahiyat Fakültesi Dergisi, 19, 38-61.

Güloğlu, H. (2019). Çizgi film karakterleri ve yan ürünlerinin çocuklar üzerindeki etkileri (Winx Club çizgi film ve yan ürünleri örneği) (Yayımlanmamış yüksek lisans tezi). Marmara Üniversitesi.

Karakuş, N. (2015). Okul öncesi döneme hitap eden tema içerikli çizgi filmlerin değerler eğitimine katkısı yönünden değerlendirilmesi (Niloya örneği). Değerler Ĕ̈itimi Dergisi, 12(30), 251-277.

Kılcan. T. (2020). Ortaokul öğretmenlerinin öğretim programlarında yer alan kök değerlerin önem sırasına ve eğitimine ilişkin görüşleri. TÜBAD, 5(2), 33-44.

Kozikoğlu, İ. (2018). Okul öncesi öğretmenlerinin değerler eğitimine ilişkin tutum ve görüşlerinin incelenmesi. Uluslararası Türkçe Edebiyat Kültür Eğitim Dergisi, 7(4), 2698-2720.

MEB. (2013). Millî Ĕ̆itim Bakanlı̆̆ı okul öncesi ĕgitim programı. http://tegm.meb. gov.tr/dosya/okuloncesi/ooproram.pdf.

MEB. (2018). Hayat Bilgisi dersi ögretim programı. https://mufredat.meb.gov. tr/Dosyalar/2018122171428547-HAYAT\%20B\%C4\%B0LG\%C4\%B0S\%C4\%B0\%C3\%96\%C4\%9ERET\%C4\%B0M\%20PROGRAMI.pdf. 
Neuman, L. W. (2006.) Toplumsal araştırma yöntemleri, nitel ve nicel yaklaşımlar (2. cilt) (7. baskı), Sedef Özge (çev.). Yayın Odası.

Oruç, C., Tecim, E. ve Özyürek, H. (2011). Okul öncesi dönem çocuğunun kişilik gelişiminde rol modellik ve çizgi filmler. Ekev Akademi Dergisi, 15(48) 303-319.

Sadioğlu, Ö., Turan, M., Deveci Dikmen, N., Yılmaz, M. ve Özkan Muhtar, Y. (2018). Değerlerin öğretiminde çizgi filmler: 'Rafadan Tayfa örneği'. İnönü Üniversitesi Eğitim Fakültesi Dergisi, 19(3), 240-251.

Selanik Ay, T., ve Korkmaz, Ç. (2017). Sosyal bilgiler programında yer alan değerler ve kültürel ögeler bağlamında "Küçük Hezarfen" çizgi filmi. Batı Anadolu Eğitim Bilimleri Dergisi, 8(2), 49-62.

Şahin, N. (2019). TRT’nin çocuklara yönelik çizgi filmlerinin Türkçe öğretimi ve değer aktarımı açısından incelenmesi. Nosyon: Uluslararası Toplum ve Kültür Çalışmaları Dergisi, 2, 1-10.

Şentürk, Ş. ve Keskin, A. (2019). Rafadan Tayfa çizgi filminin milli ve evrensel değerler açısından değerlendirilmesi. Eskişehir Osmangazi Üniversitesi Sosyal Bilimler Dergisi, 20(Özel Sayı), 1-15.

Ünlü, İ. ve Kaşkaya, A. (2018). Sosyal bilgiler öğretmenlerinin değer eğitimine ilişkin görüşlerinin incelenmesi. Uluslararası Türkçe Edebiyat Kültür Eğitim Dergisi, 7(4), 2656-2679.

Yaman, E., Bayburtlu, F. İ., Tekir, B. ve Kırman, S. (2015). Dede Korkut çizgi filminde yer alan değerler. Değerler Eğitimi Dergisi, 13(29), 245-269.

Yazıcı, E., Baydar, I. Y. ve Kandır, A. (2019). Çizgi film ve çocuk: Ebeveyn görüşleri. Adnan Menderes Üniversitesi Eğitim Fakültesi Ĕ̆itim Bilimleri Dergisi, 10(1), 10-19.

Yıldırım, A. ve Şimşek, H. (2008). Sosyal bilimlerde nitel araştırma yöntemleri (7. bask1). Seçkin Yayıncılık.

Yorulmaz, B. (2013a). Din ve değerler eğitimi açısından Caillou çizgi filminin değerlendirilmesi. Diyanet İlmî Dergi, 49(3), 127-143.

Yorulmaz, B. (2013b). Pepee çizgi filminin din ve değerler eğitimi açısından değerlendirilmesi. Uluslararası Sosyal Araştırmalar Dergisi, 6(24), 438-448. 
Extended Abstract

\section{Investigation of Diyanet TV Cartoons in Terms of the Values Included in the 4-6 Age Group Koran Courses Curriculum}

Semra ÇINNEMRE, Corresponding Author, Assistant Professor.

Trabzon University, Faculty of Theology, Trabzon / Turkey.

semra.cinemre@trabzon.edu.tr

https://orcid.org/0000-0002-2924-1129

Article Type: Research Article

https://doi.org/10.34234/ded.857721

Received Date: 10.01 .2021

Accepted Date: 31.03 .2021

Published Date: 25.06.2021

\section{Introduction}

With the spread and diversification of information and communication technology tools day by day, the roles of the family and school, such as presenting and socializing, have been actively taken by these tools. In this context, the function of mass media as a non-formal education tool is an issue being approached from various angles (Arslan, 2016, ss. 8-9). Looking at the issue from the dimension of children; it is a well-known fact that apart from the conventional institutions such as family and school, mass media play a role in many aspects of their lives. Thus, various studies have stated that especially cartoons can have positive or negative effects on various developmental domains of children from early childhood stages (Büyükbaykal, 2007; Oruç vd., 2011; Cebeci ve Demir, 2018; Güloğlu, 2019; Yazıcı vd., 2019). 
The feature of mass media as a non-formal education tool in various themes is also case in terms of religion and values education. In this regard, this study contends that the mass media can play an active role in presenting information about religion, creating religious identity and acquiring religious behavior or attitude, in this sense, the media can be considered as a non-formal religious education tool (Furat, 2009, s. 56). Considering these developments, the Presidency of Religious Affairs has taken important steps in utilizing the possibilities and widespread influence of mass media. In this respect, the Presidency has established a television channel called "Diyanet TV". The Presidency broadcasting programs on Diyanet TV channel that appeal to various target audiences. Cartoons are among these broadcasts that targeting children.

In this study, cartoons on Diyanet TV channel will be analyzed in terms of values acquisition. This study hopes to contribute to improvement of the quality of Diyanet's broadcasting service for children by bringing different angles to it. Since the study focuses on object the service of the Presidency, the values in the 4-6 Age Group Koran Courses Curriculum, which is another common religious education service of the Presidency, will be taken as a basis in determining the analysis categories. Accordingly, the main problem of the study is determined as follows: "Do Diyanet TV cartoons offer content that supports values acquisition?"

\section{Method}

In this study qualitative research method was adopted, which include the use of document analysis. Accordingly, cartoons will be analyzed as a document by content analysis method.

\section{Sample}

There are six cartoons that have been broadcasted or being broadcasted on Diyanet TV. Dedemin Öyküleri and Yusuf'un Dünyası were determined as the sample of the study with typical case sampling. As episode sampling first 10 episodes from both cartoons were selected. The broadcast times of cartoons vary between 6-12 minutes.

\section{Research Process}

The data of the study were collected via the web page of Diyanet TV channel (https://www.diyanet.tv/cocuk). The obtained data were analyzed by content 
analysis. And open coding method (Neuman, 2006, ss. 468-471) was preferred in the study. In this context, the content on the surface was coded considering only the verbal contents; whereas contents sought with implicit coding (Neuman, 2006, ss. 468-471) such as sub-messages and connotations were not evaluated. In terms of the reliability of scientific research, it is stated that the open coding path is quite reliable (Neuman, 2006, ss. 470-471).

The category system and related coding is a very important stage in content analysis. In determining the analysis categories of this study, the 4-6 Age Group Quran Courses Curriculum was taken as basis. Since the Religious Knowledge-1 learning area in this Curriculum consists of value concepts, its unit names have been taken as an analysis category with some changes. As a result, the following 11 analysis categories were determined: Justice, Truthfulness/Honesty, Favor, Compassion, Apology, Patience, Respect, Love, Responsibility, Thank God/ Thanks, Help.

Direct quotations are presented in order to increase the validity of the research and to ensure compliance with the transferability criteria, sections from cartoons or contexts were frequently used in the presentation of the findings.

\section{Findings}

In this section, the findings will be presented according to the value titles determined as analysis category.

\section{Findings regarding the value of justice}

The value of justice is mentioned twice in the Dedemin Öyküleri cartoon, and it is seen that this value is not included in Yusuf'un Dünyası. Compared to other cartoons examined in the literature, both in terms of scope and the occurrences of the value of justice, Diyanet TV cartoons found to have limited scope representation of the value.

\section{Findings regarding the value of truthfulness/honesty}

The value of truthfulness/honesty is mentioned three times in the cartoon of Dedemin Öyküleri and once in Yusuf'un Dünyast. It was observed that the content presented in cartoons regarding the value of truthfulness/honesty was mostly focused on increasing children's awareness regarding this value. Comparing 
results with existing literature, it is seen that the occurrences of the value of truthfulness/honesty is relatively limited in Diyanet TV cartoons.

\section{Findings regarding the value of favor}

In the analysis, it was seen that this value was not directly included in both cartoons.

\section{Findings regarding the value of compassion}

The value of compassion occurs once in the cartoon of Dedemin Öyküleri, and it is seen that this value is not included at all in Yusuf'un Dünyası. The value of compassion is included in a broad context in the 4-6 Age Group Koran Courses Curriculum. It should be noted that the cartoons have confined very limited space in their content for the value of compassion.

\section{Findings regarding the value of apology}

It is seen that the value of apology occurs three times in Dedemin Öyküleri cartoon and 13 times in Yusuf'un Dünyast. It is a well-known fact that teaching children to confer thanks or to apologize are central to the social development of the preschool child. It has been found that apology as a value is conveyed through the language of the heroes in cartoons which can be regarded as a method of observational learning (Modelling).

\section{Findings regarding the value of patience}

The value of patience occurs five times in Dedemin Öyküleri cartoon and once in Yusuf'un Dünyası. It is remarkable that the value of patience in cartoons integrated with cognitive dimension and real-life examples, making the value understandable and persuasive in the eyes of the child which makes it more effective.

\section{Findings regarding the value of respect}

Regarding the value of respect, it has no occurrences in the cartoon of Dedemin Öyküleri, but it occurs twice in Yusuf'un Dünyası. Compared to other cartoons examined in the literature, the place given to respect in Diyanet TV cartoons is 
rather limited. Considering its important place among all values, the study suggest that it is necessary to give wider coverage to value of respect that integrated in daily life in cartoons.

\section{Findings regarding the value of love}

It is seen that the value of love occurs three times in both cartoons. Compared to other cartoons examined in the literature, it is seen that the place given to love in Diyanet TV cartoons is rather limited. Considering the place of love in human life in general and in a child's life in particular, it becomes evident that the value of love should be given more place in cartoons.

\section{Findings regarding the value of responsibility}

The value of responsibility occurs once in the cartoon of Dedemin Öyküleri and it is seen that this value is not included at all in Yusuf'un Dünyası. In order to instill this value from the early childhood stage, it would be appropriate to include content in cartoons that make children realize that they have various responsibilities in life.

\section{Findings regarding the value of thank God/thanks}

It is seen that the value of thankfulness occurs three times in Dedemin Öyküleri cartoon and 13 times in Yusuf'un Dünyast. Thankfulness is also one of the basic values, especially in terms of the social development of the preschoolers. In this context one of the successful aspects of Diyanet TV cartoons is its tranferring this value through everyday life situations and language of the heroes in the cartoons.

\section{Findings regarding the value of help}

It is seen that the value of help occurs 13 times in Dedemin Öyküleri and 30 times in Yusuf'un Dünyast. It has been observed that help is one of the most frequently mentioned values in many cartoons examined in the literature, the same applies to Diyanet TV cartoons. It can be said that one of the successful aspects of Diyanet TV cartoons is that helpfulness as a value is included in both cartoons in various contexts, incorporated with affective and cognitive dimensions. 


\section{Conclusion and Discussion}

The main conclusions to be drawn from the study can be expressed as follows:

It is seen that in the example of values of help, patience, justice and responsibility, the value is transferred with reference to children's daily life and thus the acquisition of these values more effective and clear in terms of the concretization of the relevant value according through their incorporation with real-life experiences.

Another issue worth highlighting is the usage of some concepts of our language, culture or religion in transferring the values. These dimensions are important for children to become familiar with the religious and cultural aspects of the value concerned.

In Dedemin Öyküleri, grandfather tells various stories, especially on life of prophets, and uses these stories as case studies. This method is appropriate in terms of consolidating the relevant value with a case study and also showing the prophets as a role model in relation to value.

The frequent display of thanks and apologizing in the flow of daily life of both adults and child heroes in the cartoons is another successful aspect that contributing to the acquisition of the most basic social skills for preschoolers.

One of the noted limitations is that the values of love and respect, which are among the most fundamental values, were given a very limited place in both cartoons. Similarly, it is seen that the values of justice, truthfulness/honesty, compassion and responsibility are transferred in a very limited scope. In this context, it can be suggested that these basic values, which are expected to be acquired by children, should be given more space in the cartoons.

Besides giving place to some values in separate sections, children's perception and understanding of values could be enhanced through reinforcing them with different contexts and incorporating them into daily life.

Finally, further studies would be required to analyze Diyanet TV cartoons in terms of their visual content, other value categories, sub-messages, implicit or additional meanings. 
Etik Beyan / Ethical Statement: Bu çalışmanın hazırlanma sürecinde bilimsel ve etik ilkelere uyulduğu ve yararlanılan tüm çalışmaların kaynakçada belirtildiği beyan olunur. / It is declared that scientific and ethical principles have been followed while carrying out and writing this study and that all the sources used have been properly cited.

Finansman / Funding: Yazar, bu araştırmayı desteklemek için herhangi bir dış fon almadığını kabul eder. / The author acknowledges that she recevied no external funding in support of this research. 